\title{
SPEED AND POSITION SENSORLESS \\ PERMANENT MAGNET SYNCHRONOUS MOTOR DRIVES
}

CENTRE FOR NEWFOUNDLAND STUDIES

\section{TOTAL OF 10 PAGES ONLY MAY BE XEROXED}

(Without Author's Permission)

M. ASHRAFUL HOQUE 




\section{Speed and Position Sensorless \\ Permanent Magnet Synchronous Motor Drives}

By

(6).M. Ashraful Hocpue

A thesis sulnuited to the Srhool of Ciratuate Studies

in partial fullillme ut of the resguirenents for the degree of

Master of Engincering

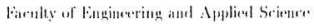

Mlemerial linversity of Kewfonudland

(1)

Si. Julun's

Kewfoundland

('antalit 
The author has granted an irrevocable non-exclusive licence allowing the National Library of Canada to riproduce, loan, distribute or sell copies of his/her thesis by any means and in any form or format, making this thesis available to interested persons.
L'auteur a accordé une licence irrévocable et non exclusive permettant à la Bibliothèque nationale du Canada de reproduire, prêter, distribuer ou vendre des copies de sa thèse de quelque manière et sous quelque forme que ce soit pour mettre des exemplaires de cette thèse à la disposition des personnes intéressées.

L'auteur conserve la propriété du droit d'auteur qui protège sa thèse. Ni la thèse ni des extraits substantiels de celle-ci ne doivent être imprimés ou autremen! reproduits sans son autorisation. 


\begin{abstract}

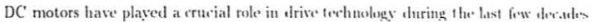
of this century: Recent developments in pewer converters, digital sighal puensors and magnetic materials nake it pessible to use as motors in at tariog of alrive oppli

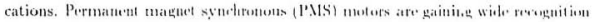

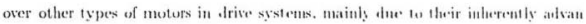

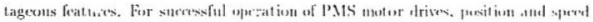
sensing are of rritical importance. ( ioncentional somours are expusive and hampн

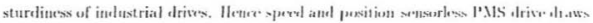

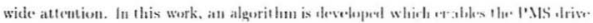

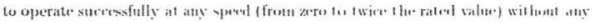

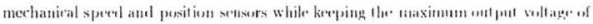
the in erter constant abowe the base specel. New expressions biave lieen deribed for

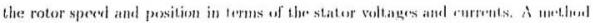
has also been suggesteul to ralenlate the input voltage of the mutor. Thar present

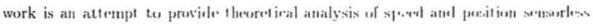
PMS drives with computer simulations of varions drive conliguations. Fxperinuental

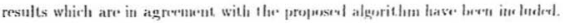




\section{Acknowledgments}

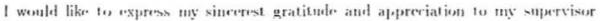

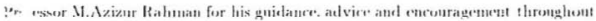
my program. My sincerest thanks to C'anadian International Develepment dgeney

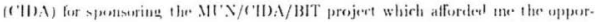

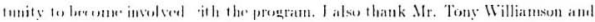

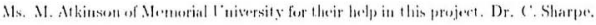

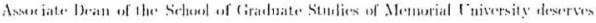
sperial thanks for his stlpurt.

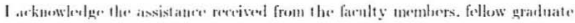

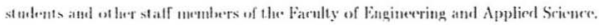

Finally I rxpress my simere appreciation to my wife, on daughter as well as ot her fanty members and friculs without whose support. cheouragentent and understanding, it would net have heen pexsible to remplete this work. 


\section{Contents}

Abstract $\quad$ ii

Acknowledgement

Contents iv

List of Figure, v v

List of Tables vi

List of Symbols viii

1 Introduction I

1.1 Brief review of motors in drise systems . . . . . . . . . . 2

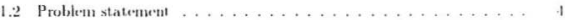

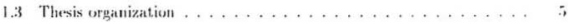

2 Litelature Survey f;

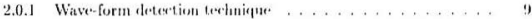

2.0 .2 Flux linkage methorl .................. 15

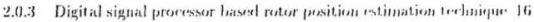




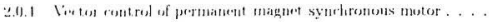

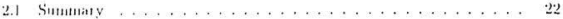

3 Analysis $\quad 24$

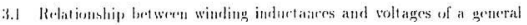

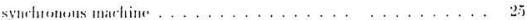

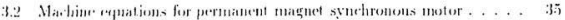

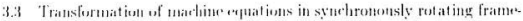

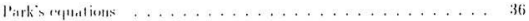

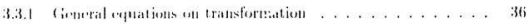

3.3 .2 l'atk's liquations ........................... 38

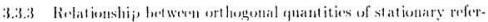

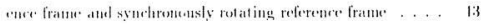

3.3.1 Relationship heswen hree-phase and orthogonal quantities in

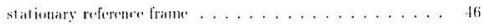

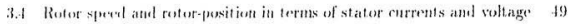

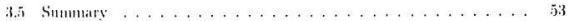

1 Simmlation of position sensorless permanent magnet syuchronous motor drive

1.1 Simulation of promatent magne synchronous motor with sinusojelal

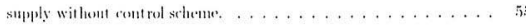

1.2 Simulation of closed hop veetor control of permanent magnet sym-

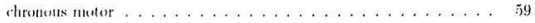

1.2.1 PMS motor drive system upto hase speed with spered ferdhatk

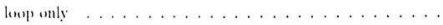


4.2.2 Current controlles and voltage sunece inwerter (lisl1 . . . . of

1.2.3 Workine principh of the alriw system . . . . . . . . tis

1.3 PXS nutur drive with two cont rol lenps ............. is

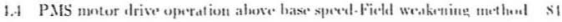

4.5 Discussions on Simulaterl Results . . . . . . . . . . . s?

5 Experimental Results

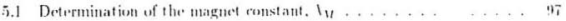

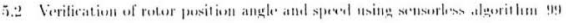

5.3 Discussions on the esperimental tesults . . . . . . . . . . III.3

6 Conclusions

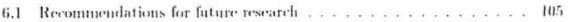

References 107

Appendices $\quad 112$

A PMS motor design data 113

B Experimental waveforms $\quad 114$ 


\section{List of Figures}

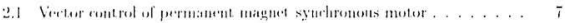

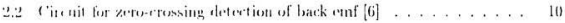

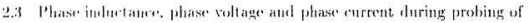

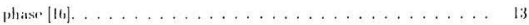

2.4 Kotor pasiliun estimat ion keleme by flux linkage methud [19] . . . 16

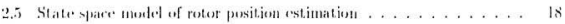

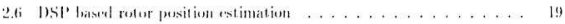

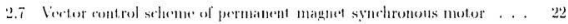

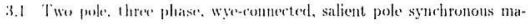

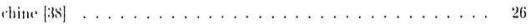

3.2 Distrihution of phase winding atud totresponding MMF $[3 \mathrm{~s}] \ldots \ldots$

3.3 Park's molet of permanent magnet syouronous motor: (a) d-axis (b)

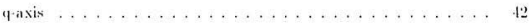

3.t (a) (10-oratinatesystems of the stationary reference frame with an initial : 0. (b) (ir-urdinate systems of stationary reforence frame with $0=0$. 46

1.1 Block diagram of open loup simulation of PXS motor . . . . . . 56

1.2 Flow rart for open loup simulation of PXS nutor . . . . . . . 5i 
4.3 Open loop simulation of PMS notur. (a) Rutor sperel. (fo) lintou

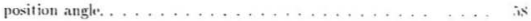

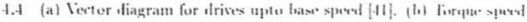
harattristics. ......................... till

4.5 Block diagram of speed cont rol loop drive system [39! . . . . . . 6.'

4.6 Voltage source inverter and current ront ruller $[39] \ldots \ldots \ldots$ ti.

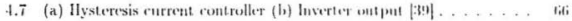

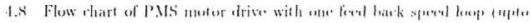

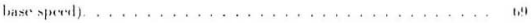

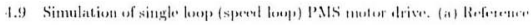

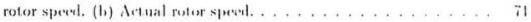

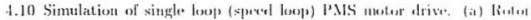
position (b) linit vecturs. . . . . . . . . . . . .

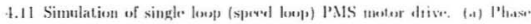

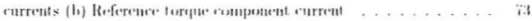

4.12 Output voltage of the inverter ............... it

1.13 Block diagram of PMS motor drive systum with two control happs. . iti

1.14 Flow chart for the computer simulation of modiliof I'WS untor frive is

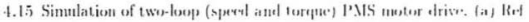
erence speerl. (b) Artual speral.

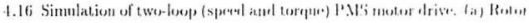
position angle (b; tinit verters. . . . . . . . . . . . XI

4.17 Simulation of two-leop (spered and toripus) P.MS motor drive. (a) Plats. currents. (b) Inverter oul put voltage. . . . . . . . . . . . . 


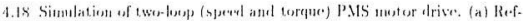

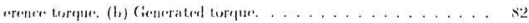

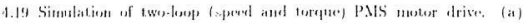

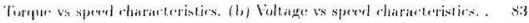

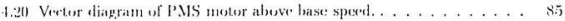

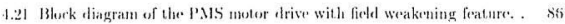

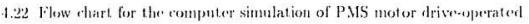

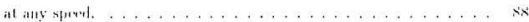

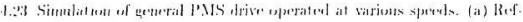

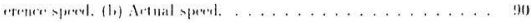

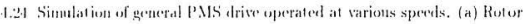
pusitien. (1,) lint vectors. . . . . . . . . . . . . .

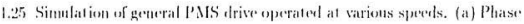

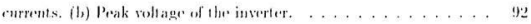

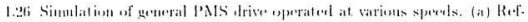

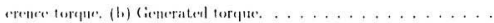

4.27 Simulation ol general P.IS drive operated at varions speeds. (a) Torque compunent intrent. (b) llimagnetizing current. ..........

1.2S Simulat ion of gemeral l'MS drive operaterl at various speeds. (a) Torgue

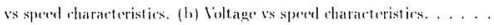

5. I Experimental set up for the determination of magnet constant $\lambda_{u} \ldots$. 9s

5.2 Fixperimental s+1up for the merifieation of sensorless algorithm of P.MS mutur. ............................. |

5.3 Simulatid and experimutal results of open loop, PMS motor: (a) Sim-

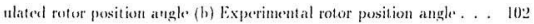




\section{List of Tables}

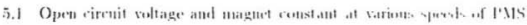
motor. ............................

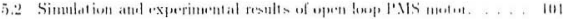

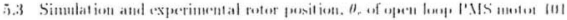




\title{
Nomenclature
}

\author{
$r_{1}+n_{1}$

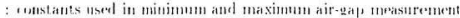 \\ 7

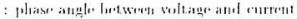 \\ n, \\ : roter tisplacruent \\ $11, n$ \\ : intial rotor pusition angle.

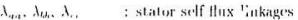 \\ If \\ : liatel silf Ihus lintiage. \\ $1,1,1$. \\ ; |rotid flux linkages in status phase. \\ is \\ : for al flus linkages in fictil \\ $|1$, \\ : Hox linkage matrix of permanent, magned rotur \\ $I_{1 \prime}$ \\ : Hatam+t romslatul \\ $\mu$ \\ : permenblility for fire spare \\ II. \\ : relitite pertacability \\ 4 \\ : stater disfoliscomenul \\ $\therefore$. \\ : Mative displarement of rotor \\ s, \\ : rotor angular spreal \\ $1,16.1$, \\ t phase cuments \\ $i, i_{i}$

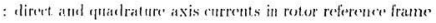 \\ i. \\ : diret and quadrature axis courents in stator referene frame \\ 1 \\ : length of air gat, \\ I \\ : opeviratur $\frac{t}{11}$

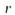 \\ : Intin radius of air gap

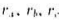 \\ $\therefore$ stator phatse resistance \\ $r$ \\ : stator phase resistance when considered eyual
}




\begin{tabular}{|c|c|}
\hline$r_{1} \cdot r_{6} \cdot r_{c}$ & : phisese voltages \\
\hline$v_{d}^{r} \cdot v_{p}^{r}$ & : direct and quitrature axis voltages in rotor reforence fratne \\
\hline$v_{4}^{s}, v_{4}^{s}$ & 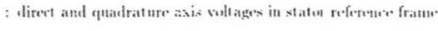 \\
\hline$I_{m}$ & : peak value of input enrrent of the notor \\
\hline$K_{1} \cdot K_{2} \cdot K_{3} \cdot K_{4}$ & : Pl: propurtional integral cont roller ronstants \\
\hline $\mathrm{h}_{5}$ & : integrator constant \\
\hline$[L]$ & : incluetance mat rix \\
\hline 1.1 & : stator leakage incluetance \\
\hline$L_{n+1}, L_{b h}, L_{w}$ & : slater solf indurtanes \\
\hline$L_{f f}$ & : ficld self indurtance \\
\hline$L_{\text {....., }}$ & : Y-insis mutal imluetance. \\
\hline$L_{n+1}$ & : A-axis mutnal indurelance. \\
\hline$L_{v}$ & ; q-axis infurtaner. \\
\hline$L_{t}$ & : A-axis indurtare. \\
\hline$L_{s}$ & : statie indutance. \\
\hline$M_{4 h} . H_{h}, M_{4}$ & : stator mutual inclurtaures \\
\hline$M_{a f}, M_{b f}, M_{f}$ & : field mutual indurtances \\
\hline$P$ & : Ximmber of poles \\
\hline$V_{b}$ & : voltage indured by vermanent. magnet rofor \\
\hline$V_{m}$ & : perak value of itupent velatge of the meter \\
\hline$V_{s}$ & : applied voltage to moter terminal \\
\hline
\end{tabular}




\section{Chapter 1}

\section{Introduction}

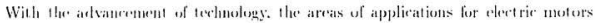

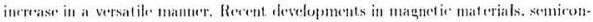

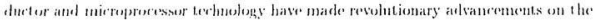

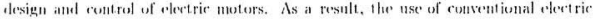

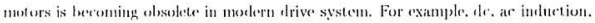

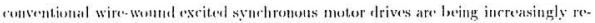
plared by the permanent magnet synchronous motor (P.MS motor) drives. The P.MS

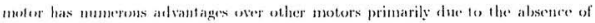

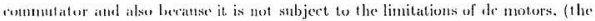
linit on tnaximum voltigg, maximum sperd, maximum power, frequent maintenatiec. and inability to uperate in explosive and contaminated environments). PMS motors cath offer significanly higher advantages and efficiency over induction marbines when

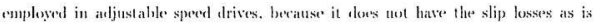
the cons with indurtion motors. Pyls motors are superior to the conventional wirewound excited stuchenous motors heranse the fiedt ecil. de supply atul slip rings are - liminated in the former which results in low power huss and less complex motor drive 


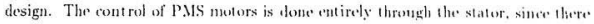
is no provision: for totor side excitation control. Vector control menlienl is genterially

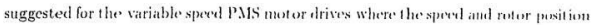

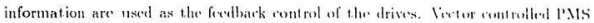

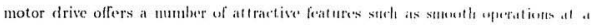

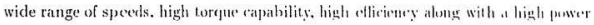
factor and compate drive design.

\subsection{Brief review of motors in drive systems}

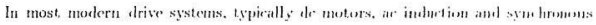
motors are widuly used.

\section{DC motors}

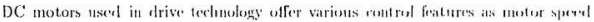

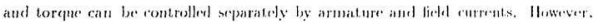

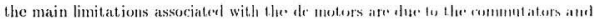

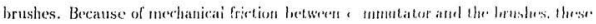

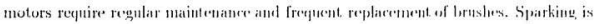

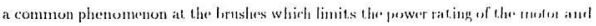
its use in explosive enviromments. Recently, electronirally commutated ar frrmithent. magnet synchronous motors known as broshless de motors an. mplariug lifre conven

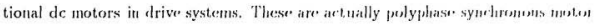
with permanent magnet rotor. The motors are exriterl by power renverters utilizing,

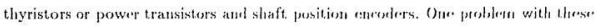




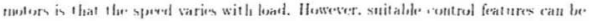
nsal to worrome this diflienly:

\section{$A C$ induction motors}

AC: influetion motors are lecing widely empleyed in trive system tue to the simplicity of construction. reliability of operation in all coviruments. availability of low ost puwer converters. digital entrot leviens, ate. However, the to slip $I^{2} R$ losses, the

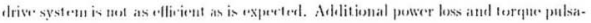
tion are two ma jor problens whith arise in indurt ion motor drives due to the higher

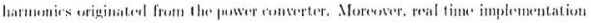

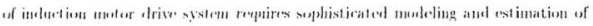

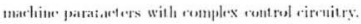

\section{Synchronous motors}

Symelanons moters of wire-wound type are commen in drive systems berause the lidfl current can be controlled from the rotor side. But dae to the presenese of the

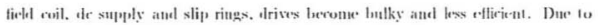
the recout developments in permanent magnet materials terlunology. I'SS motors are locoming increasingly penplat in drive applications. These types of notors are tot subjet to the limitations of ife at indurtion and wire-wonted exrited synchronous meters as preniensly alisenssul. The field excitation of these motors is obtainerl ly sntabiy menuting permanent magnet materials in the rotot. Ferrite and rate

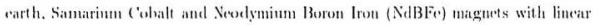
magnetizing thatreterist ies in the serond quadrant are employed in the rotor. Ferrites are commonly used hecause of the low cost. but the rare earths and XilBFe permanent 


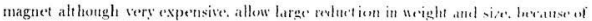

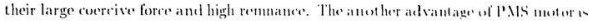

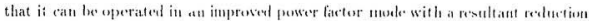

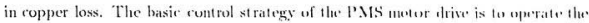

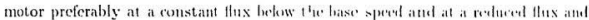

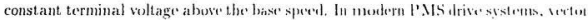

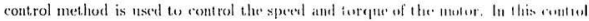

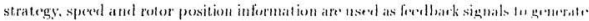

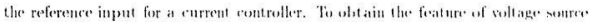

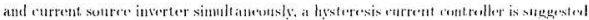

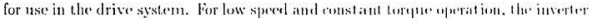

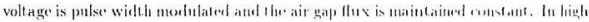

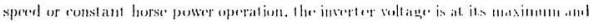

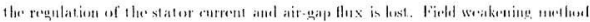

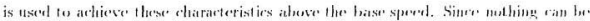

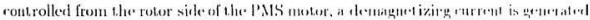

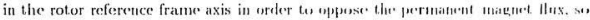
that the inverter ontput voltage rematios at its reiling value.

\subsection{Problem statement}

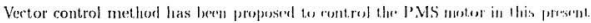

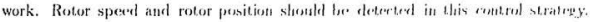

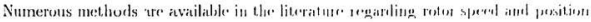

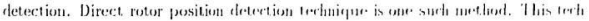


nirpun-uses tacho-generaters. Hall effert elements, optical or inductive coupling sensors.

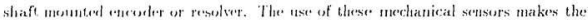
trive system lutky. less eflic ient and expensive. In some fields of application such as the submersible moter ifrive, these sensors are totally musuitable for use. Thus an indirect method of rotor position dotertion which detects the rotor position and caldenlates the rotor spent from the stator variat)les (such as st ator voltages, currents. flux linkages and stateor indurtineses), is investigated for the vertor entrol of PMS

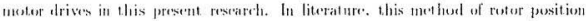

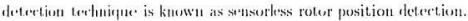

\subsection{Thesis organization}

This thesis consists of sis chapters: ("hatuter two provides the litrat ure survey of

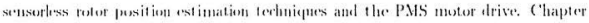

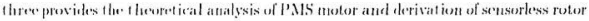

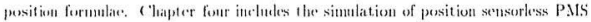
motor arive for aliferent ronfigurations. ('hapter five provides some experimental

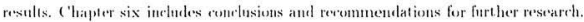




\section{Chapter 2}

\section{Literature Survey}

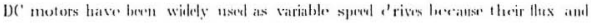

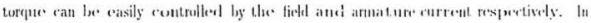

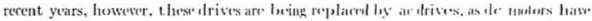

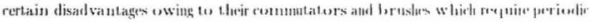
maintenature atel men replacenterents.

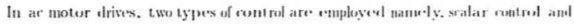
vertor control. Sralar coutrol relates only to the magnitude of a sariat,les and theit

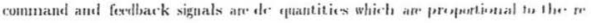

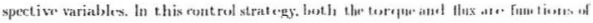

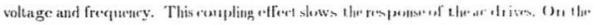

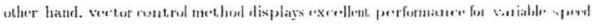

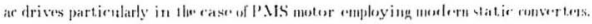

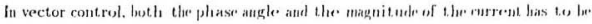

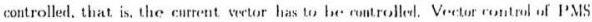

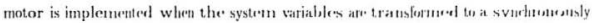

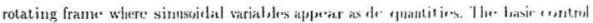




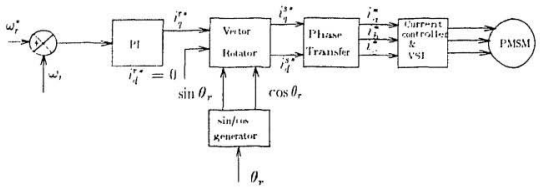

Figue 2.1: Vector control of permanent magnet syndironesus moter

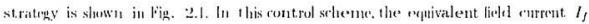
of permannen magnet rotur is consideres to be constant. The marline torque ran le controlled with constant air gap flux by rontrolling the magniturfe of chadrature

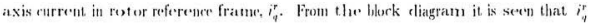

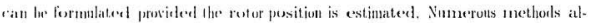
revely exist in literatume for the detedtion of ruter pesition. Thest: can be categurized as direst position sorsing and indirert position sensing. Conventional rotor position tereluigue falls under direret position sensing method which is based on the use of tathe-generators, Itall effece dements, optical or inductive ronpling sensors, shaft momtect encoders or resolvers. The usi' of these medhanical sensors makes drive sysleous complix and costly. In some arras of application such ats in submersible motor Irives, these lypes of position sensurs are unstitable. Thens iadirect position detertion berduique has bern invertigatted which replares the mechanical sensors. This method of position detect ion is hased on the masturement or identification of some clectrical quatlities of stator plase winding cirruits, such as stator phase currents, voltages or incluctatues ite. which provide information about the pesition of the roter at aty 
instant. This type of rotor position detection techuique is known as the serusorless rotor position detection. Som well known and astahlished stasorless folut pusition

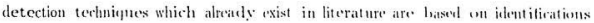
or measurements or compuntations of stator sariables. Among late wiblets aterepted methods are rotor position estimation by wave-form devert ion fechuique. Hux link age method and computation based rotor position detection. In wave-form defertion technique, sone specific events of electrical gutant it ies ate ide ontilied sum as maximum value or zero crossings in the wave-forms or thanges in stater inductaners which result

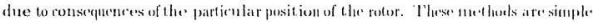

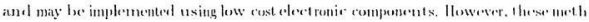

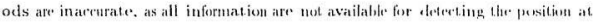

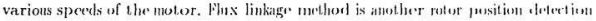

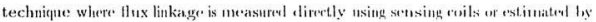
integrating the phase voltage and enmpared with a refirence Hux linkige after which

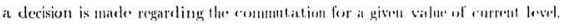

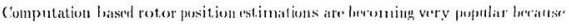

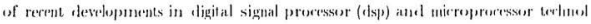

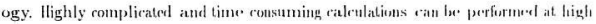

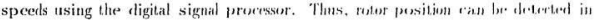
real time by analyzing phase currents and valtages sery enteveniomly. In partien lar, complex implementation of fiehl oriented or vectur condol of ar drives where rotur position detertion is messsary heremus an atotrative foature whon waing this

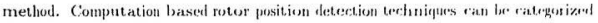

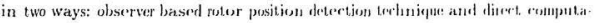

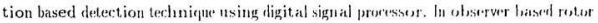


pusition detertion tachnique. an observer is designed using estimated states such as l.wo shator anrents, rotur velocity and rotor position. A feedback loop is used to generate an erres signal which is used in an iterative matuer to rorrest the states of the system. Because of iteration. the whole system might be slow and complex. (On the other hand, it is prossible to use rigital signal processor directly to detect the pessition of the rotor if the relation between the rotor position and the stator variables ran be tatiblishud. Thus the input of the processor would be currents and voltages while the ontput would be rotor position and rotor sperel which can be ased for lbe

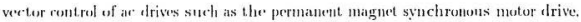

The lirst part rontains the ritical neview on the works of sensurless rotor position detection of an motors atd the serend part contains the reviews on the vertor control of itt drives.

\subsubsection{Wave-form detection technique}

'This tohnigun nes particular characteristics of electrical wave-form which are due to the position af the rotom. Defertion of back enf and monituring changes of indurtaners for the estimation of rotor position chidly lall under this category.

\section{Back enf method}

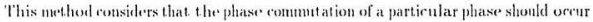
when the bak inf of that phase crosises the zero position. It an be mathenatically shewn that this zero-crussing point is athered when the terminal volt age is equat to 1.he netutral volfage. To ol. th the correct signals for the bases of the transistor inverter it is neressary to delay this point by y0 electrical degrees. Firstly, the terminal voltages $\mathrm{l}_{2}, \mathrm{l}_{\mathrm{h}}$, and $\mathrm{l}_{i}$. $\&$ couverted to the triangular wave-forms through low pass 


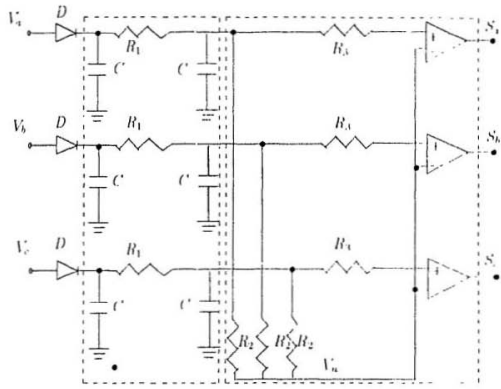

filter seretion

('omplatatior sevel iun

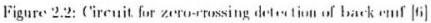

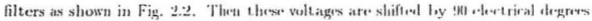
and compared with the nentral voltage $V_{n}$. Pulse signals $S_{a,}, S_{h}$ and.$S_{\text {, are }}$ produred

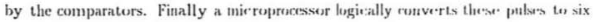
drive signals of the inverter. The performane of the whole trive systan is quite sat isfactory but the probiem associaterel with it is the starting of the nustor. A soparate. starting scheme is necossary for this type of pesition somserless hive. Wave-fentu detection techniques inrorporatiog bark-1mf for the estimation af rotor position for permanent magnet step motors are introducenl by line et. al. [1]. This is the hasic introductory paper where detailed thathematical mordels are properal to present the 
Artertion siluane. In particular. praks of voltages across the live phases and zero romsing of back emf in the nuenergized phases are sensed and information are obtaines which are utilizal for the disection of rotor position with the mathematical ixpressions presented. Hair [2] has reported an excellent feature of bark omf folect roInotive fore) detection technigue for a two phase stepping motors. The motur is operated with only one phase energised and the wher phase is completely turmed of and magnetically derouplent from the on-phase. The back emf of the off-phase

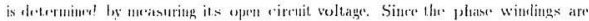

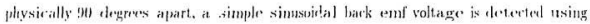
the thillenential amplifier eirnit. The rate of decay of current in off-phase nust be

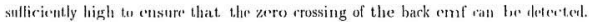

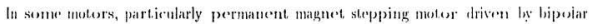

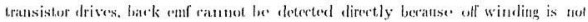

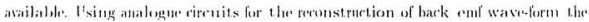

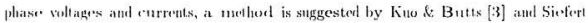
[4] te rontool the phase excitation in surh a motor, Antognini [5] has reporter] at alternatien form of back enf reconstruction terhnigne where time constant with and

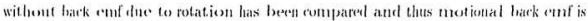

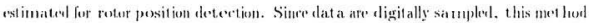

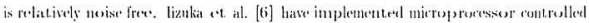
sinsorless brushless motor drives using the method that permits the determination of fermanent magne syuthronous mutor rotor position by the back ent indured in the stator winting. Thuir work experiences a setback hecause of the problem of starting, In anot her paper dntognini [7] has proposed a new way of monitoring the bark emf of

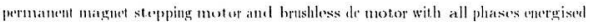


and full torque generated. In his work. he suggested that the phase wineliugs he connected in such a way so that the generated back enf voltage differnoce iat at pair of phase windings is not a function of phase current or phase impustanes. 13rerra et al. [8] have presented a mothod of rotor pesition tetertion ly extruting infumation

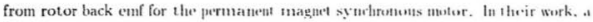

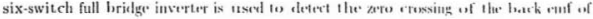
the motor by exciting two phase's of a wye connerted notor at wath time instant. Fhe.

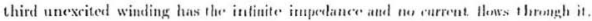

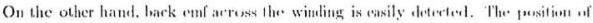

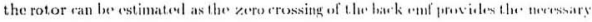
information.

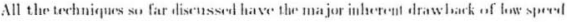

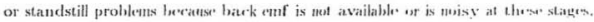

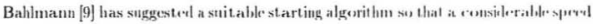
can be achievel for the deturmination of bark rul.

\section{Detection of rotor position by monitoring the changes of stator indurtance}

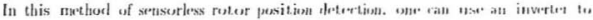
probe the phase of an ar motor by alternate switching to generate the rurrent pulsos.

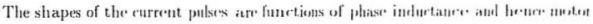
position as shown in Fig. 2.3. A prak current pulse ${ }_{n}$ is givin loy the following. relationship:

$$
i_{p}=\frac{V T}{I .\left(\theta_{p}\right)}
$$

where $V$ is the inverter voltage. $T$ is time perionl for which the phese is switefued 

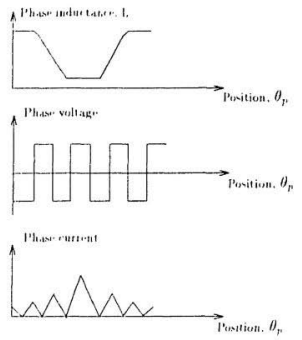

Figure 2.3: Phose indutanes phase veltage and phase current turing probing of phise ||lif.

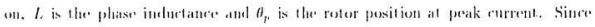

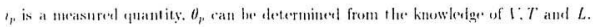
Hence, the stater winding inductater is a funtion of rotor position of permanent

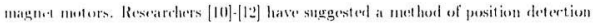

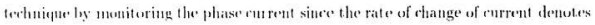
lle. incremental thange of rotor indectanes which in turn dictates the position of the roter. lins and Kino [1:3] have used the change of stator inductance for the est imation of rotor frosition of a single stark variable felat ane motor. They reported that the step of the motor is dictated ty monitoring the currents of the independent phases

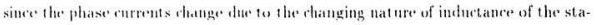




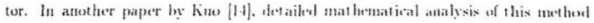
is given and it is suggested to monitor the corrent of the phase whith hats just luesn

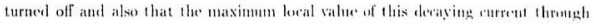
the fly back circuit be observenl. One important alvantage of this methent is that it is applicable to low sperds even at standstill where the bark ene is insignilicant. However. the relationship bet wern the rate of thange of enrrent and roter furition becomes complicated berause the incremental change of indurtance deperots on the. phase enrtent itself. Furtlermere, the batk enf atferts the current at high spervis a..

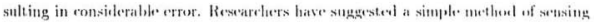

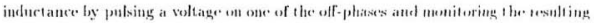

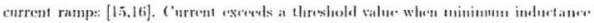

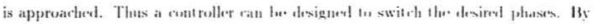

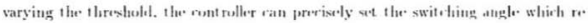
sults in a faster moter response. Fisiani et al. $|17|$ hase presented an alternative

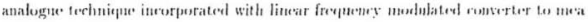

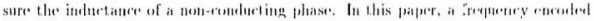
signal is generated whese time periont varies linearly with the phose inductature. The

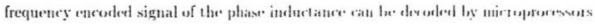

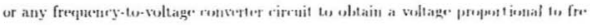

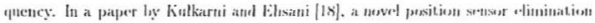
technique for interior permanent magnet synchronous motor drive is prepusad. Vising

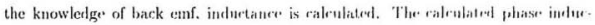
tance is then userl to estimate the fotor pasition with the help of a lowk up talshe. A scauning algorithm is usted which searders for a value of phase indurtaner that is closest to the calculated salur. 
As mentioned previensly, the mothod of rotor position detertiun by monitoring the change of staber induetance is unt very reliable, because inductance variation is merisured loy mesuring, the rhange of stator current, which in effect is not dirertly proportional to the statur inductance at any speed of operation due to the compling affert of both and alse beatuse the back emf afferts the phase current at high sperds.

\subsubsection{Flux linkage method}

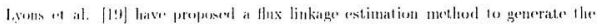

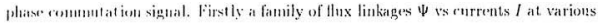
roter positions are defermined. Then these data are stored in a look-1tp lables. The estimaterl llux linkage if an la. found from the following relationship using measured vidus of phase vollage and rurrent.

$$
\dot{\psi}=\int(V-I R)
$$

where $T^{\circ}$ is the applied voltage and $R$ the winding resistance, $A$ reference value of Hux linkage W, ran be defermined for a desired value of roter pesition $\theta_{r}$ from the storal information with a known phatse conrent $l$. A comparator ats shown in Fig. 2.4 is used to compare the estimated amel refereme flus linkages. When the error $\Psi_{+}=$

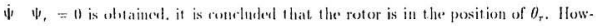
Wet, this methed sulfers from motsurement errors at the extreme angles of no-load and hary-load conditions, linugrul and Acarnley [20] proposed an improved llus linkage methoul where the terminal voltage and line currents are used with the aim of estimating the winding flux linkages. At each time step. using previous predicted position information and the flux linkige value, the line current of the motor is esti- 


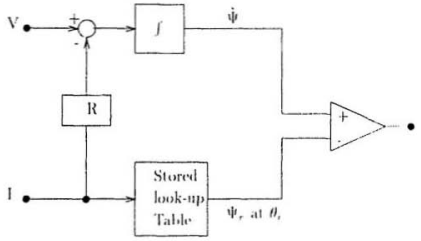

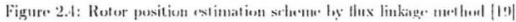

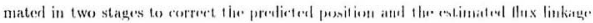
respertively:

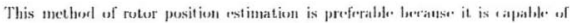

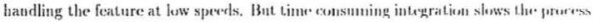
and hence is not suitable for fast response llives.

\subsubsection{Digital signal processor based rotor position estima- tion technique}

Observer based rotor position estimalion and mieroproressis or tigital signal pru

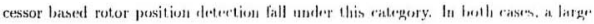
anount of mathematical ralculations and romputiolions are involved and hane the requirement for fast digital prorexsers. 


\section{Observer based rotor position estimations}

()kongwn, at al. [21] have develepeed a simple linear observer on linearized motel of an an machine where it is shown that the olserver's performaner is quite satisfacbery for small perturbations alorst a wirle raige of operating points. Lumsdaine, et al. [22] have propesed an observer methot for the variable reluctance motor where phase induetance variation uffects lluxes in the phases have been taken inte acroment. Lumsdaine and laing [23] have proposed a state observer method which is driven by measarements of phase voltage ind current for variable relactatere motor. A non-

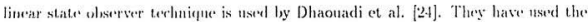
extencled kaluan lilter approach for the on-line estimation of the spered ant rotor pesition ly only using measurements of motor voltages and currents. This wotk is

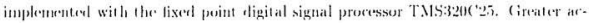

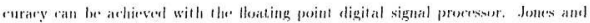

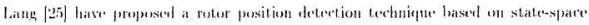

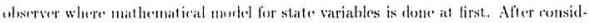
ering a unuber of factors which might. lead to error, an olserver is proposed which is non-linear in nature. The blewk diagram of a rotor position observer is shown in Fig.

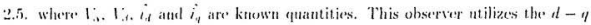

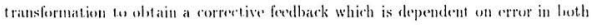

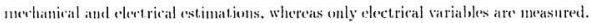

The main drawbitel of this uhserver hased rotor position astimation terhnigue is that it is very complex to implement in real timse. 


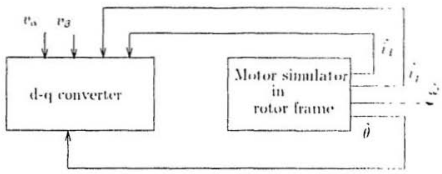

Figure 2.5: State-space moelel of rotor pusitim e-stimat iun

\section{Digital signal processor based rotor position estimation}

Revent developments in digital signal processing and micropremesor loisal cont rol tools have encunaged many researchers [26]-[32] to carry ont works ly analying ant computing the real time variables as phase currents or phase volfags. Amumg then

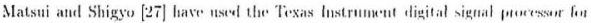

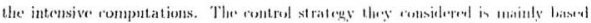
on voltage erpations. The blork diagran of this systom configuation is given in Fig. 2.6. In this work. measured value of rurrents aut remputational violues of voltages are used to estimate the rutor position $\left(\theta_{4}\right)$ whirh is then conupareal wilh it reference value of $\theta_{4}{ }^{\circ}$. The error is applied to proportional integral (J'l) ront rollers ant reference currents are produced acrordingly. Comparing the refortare rutrents with

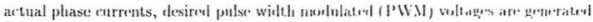

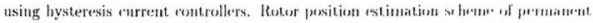

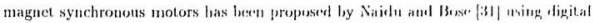
signal procossors. but detailed implementation is alorot. in this repert. Striugrimssent and Astrom [32] have propesed a digital signal processor implanuntintion if : disk 


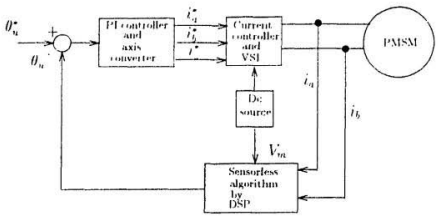

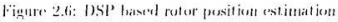

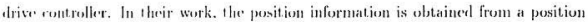
detector whith penerates a voltage. The generated soltage is proportionat to the

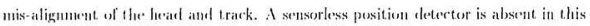
work.

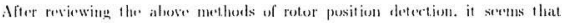
all nuthers with the exteption of the digital signal processor hased computational

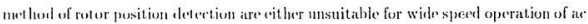
moturs, of give slow respense or are very complex to implement in real time. Control of ac moturs an be carrind out at varions spends using the digital signal processor bascd compulational method and no anditional starting systom is meressary:

\subsubsection{Vector control of permanent magnet synchronous mo- tor}

As ment innel carlier. P'MS motors can be controllenl vertorically provided the positioss and sperel of the rotor are determind. In the previous sections. works on the 
sensorless rotor position defertion were reviewed. In this sertim. works un wetur control of different types of ar motors with and without position somsors has hert reviewed and linally ronchusion is mate as to why romputation basal pusition soll

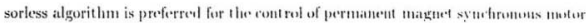
drives. Lessmeier of al. [3:3] have comparted the performante of symehromens meturs and induction moturs incorporating microprocessors. They have propesent the swetur control strategy of ac motors in a synchronously rutating franu axis. Quariature axis current has bevn identilied as a rontrol paramerer up to hase spavt and after thet

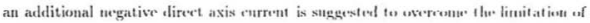

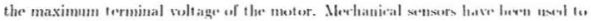
detect the rotor position rather than the conerept of sellsurless eprerat in of the moter.

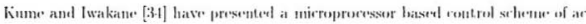

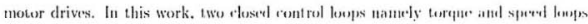

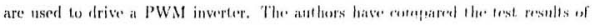

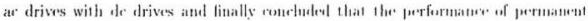

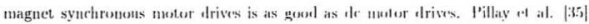
have presented the vertor and eurrent controllers for permanent mannet, syu- hromesus motors. A resolver is propesed to sense the pusition of rotor which is analyand by digital signal proressor to give the position signal. This signal is romparrel with a reference to produce rommand spered, whith is compared with the real spered and the error signal is used to produce reforence currents. lising the current rentrollen, drive

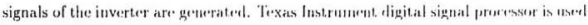

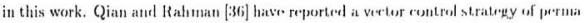
nent magnet hysteresis syuclatonous motor drives incorperating a mingoprocossor. In this control scheme. a tarhumeter is used to seruse the spared which is forl to a sin/cos 
gerustatur w profure the diret: and puadrature axis enrrents. The main control loop cousistis of two nested idesed control boops. The iuner bop is the fast response current lesp with Pl) contoullers and the slower onter loop is with PID controllers. Their simulated results have lemen verified esperinentally. Matsui and Ohashi [26] haue

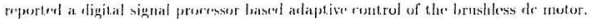
In this work TA1S32u(25) Trexas Instruments digital signal processor is userl to im-

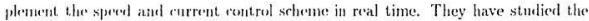
ellert of parameter sariateon on the performance of the drive. The important feature of their work is that the motor parameters usal in the controller are jelentilied

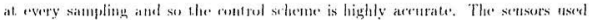

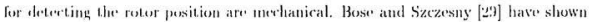
simulated results of micro-comjuter based control of an interior permatuent magnet. synchronens miahine. This drive system includes a constant torque region with zero spurel operation and field werkening constant power regions at high speeds (above

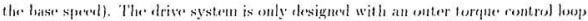

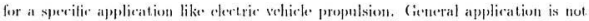
pessible with this Iype of drive as pusition and spend control loops are absent. In this drive systim. an absolate shaft pesition incoiler is propesed to defere the position of the robur. Naidu and Bowe [31] have simulated a position semsorless permanent. mag-

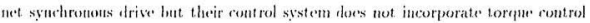
loup and motor sperd is limited up to the base spered.

A position sensotess permanent magnet syntionous motor drive on be implemented in the following way [37]: The block diagram of control scheme is shown in Fin. 2.7. In this work, two line-10-line soltages and two stator cittrents are sensed and processed in an analogue form to produre the stator flux linkage vertor. These 


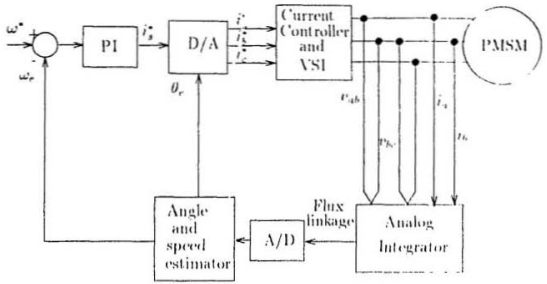

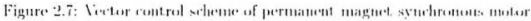

flux linkages are processed and lilered to oblain information alont rofor pasition of and speed $\omega$ whith are nsed to produre reference stater currents. The thare pheme

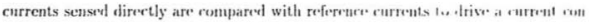
troller which thus generates the alrive signals for the inserter. Fixpriusutal asult:

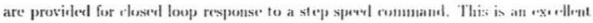

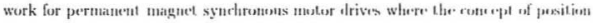
and speed sensorless opuration is implemented. But this type of itrive system always has the problem of starting. A separate starting stratigy is inturluecet whirh makes the system complex. 


\subsection{Summary}

In ronelueling this rhapter it can be stated that there is a need to tlesign a positien sensorless permonent magnet drive which can be operated at any speed without. any separate: statting system. After reviewing works of rotor position estimation for vertor controlled permanent magned drives. computation based digital signal processor implementud rotor pusition detuetion technicas is preferred for this present work leranse of the following reasons:

1. Drive can be uperated at any specel without any additional starting rircuit.

2. Hesause of inherent arcuracy of the digital signal processor. the propused drive wustel he very efliciont.

3. Since cump' ₹ mathematiend atculat iuns can be carried out by the digital signal

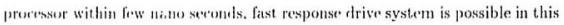
viase. 


\section{Chapter 3}

\section{Analysis}

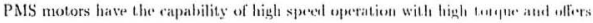
smooth torgue operation even at, very low sperds. These dharatarist in of permanem

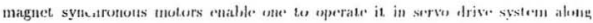
with the vector control seleeme. The hasir principle of artar control unethen is that it needs magnitude as wril as angle information of coutrollable sarialbes. Keotor position deternines the angle of the sariable and its detertion is one of the hasie requirenents for this type of irive applieation. Numerons me-therls at. foum in

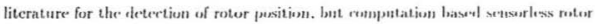

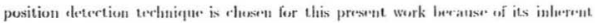
accuracy and fast response chararteristirs when usen with a sperial type of oligitiol signat proressor. A compart form of rotor position detertion algorithu is passilate

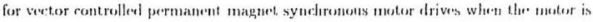

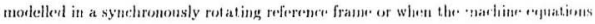
are expressed in Park's tratsformation. In order to do so, the fiollowing stopls have been takin. 
- Reliatienslip berween marhinu indiartiture and voltage is established for synchromusus mations in general.

- Vollage cophations aro formed in mathine variables for permanent magnet synchronous mathium variables.

- Heference frame theory is applied to transfer the machine equations from staLionary frame axis with stater variables to synchrononsly rotating reference frillur.

- Eiguations relitine to rotor pusition detectiont are derived using the madhine modol in son-hromonsly puating trame.

\subsection{Relationship between winding inductances and voltages of a general synchronous machine}

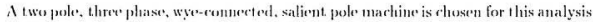
as shown in Fig. 3.1. If $\left(o_{1}+o_{2}\right)^{-1}$ and $\left(o_{1}-o_{2}\right)^{-1}$ are taken as minimum and Haximum air gap length, then that air gap is approximated by [38]

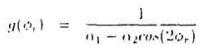

lut since

$$
\therefore=\left(\omega_{r}+\theta_{r}\right)
$$

"l'ken it an be written that

$$
n\left(0,-\theta_{1}\right)=\frac{1}{a_{1}-a_{2} c^{2} 0 s_{2}^{2}\left(\theta_{s}-\theta_{r}\right)}
$$




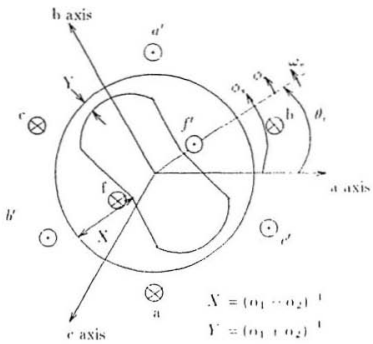

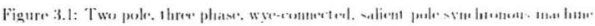
$[3 x]$

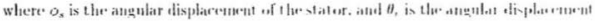

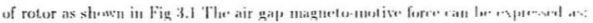

$$
M . \mathrm{HF}=H=y=\frac{B,}{\mu_{0}, \mu_{u}} y
$$

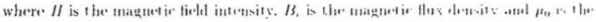

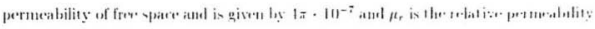

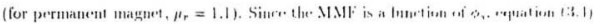
ran be monlified tus

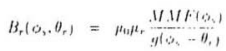

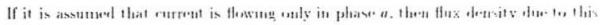




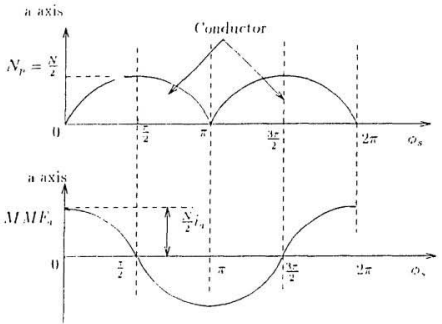

Fignre 3.2: Distribution uf phess winding and curresponding MIMF [3S]

is givinl lis

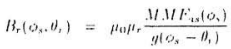

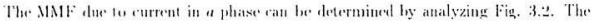
sullix s stands for the slator quantity and is not repesaled in the remaining text for the sake of simplicity. The winding distribution is taken as sinusoidal which is exprested for stator, aphase as

$$
\begin{aligned}
x_{1}=x_{1} \sin \theta & 0 \leq 0 \leq \pi \\
x_{1}=-x_{1} \sin \theta . & \pi \leq 0 \leq 2 \pi
\end{aligned}
$$

where $I_{p}$ is the maximum number of turts expressed in turns/ranlian. If $I$ is con-

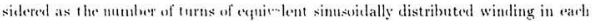


phase of the stator, then

$$
x=\int_{10}^{*} x_{i} \sin 0 d 0=2 x_{l}
$$

Therefore.

$$
x_{p}=\frac{x}{2}
$$

Now it is assumed that the fielel winding is sinusoidally distributerl with . N, cyuisalent turns as:

$$
x_{f}\left(\partial_{r}\right)=\frac{x_{f}}{2} \cos \partial_{r}
$$

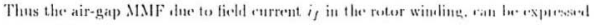
ns

$$
M \| H_{f}=-\frac{v_{f}}{\underline{y}} i_{f} \sin \theta_{,}
$$

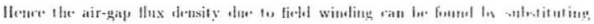
equations $(3.3)$ and $(3.12)$ in copation $(3.4)$ as:

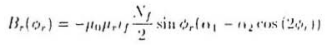

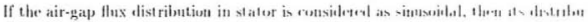

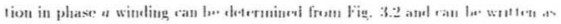

$$
H . H H_{a}=\frac{N}{2} i_{4} \cos \theta
$$

Similarly for the other two phases $b$ and $r$ it, ran be writuen that

$$
\begin{aligned}
& M . M F=\frac{1}{2} i_{0} \cos \left(a-\frac{2 \pi}{3}\right) \\
& M H F=\frac{1}{2} \cos \left(a \cdot \frac{2 \pi}{3}\right)
\end{aligned}
$$


Substituting apuat iens (:3.3) and (3.1) in equation (3.5). the expression of flux density dies to courrent only in phase a ferecomess

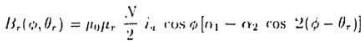

Similarly, the flux atensilies for aurrent in phase b aurl $r$. respectively are given as:

$$
\begin{aligned}
& B_{r}\left(\omega, \theta_{1}\right)=\mu_{0} / \mu_{r} \frac{N}{2} i_{1} \cos \left(\omega-\frac{2 \pi}{3}\right)\left[\omega_{1}-\theta_{2} \cos 2\left(\theta-\theta_{r}\right)\right]
\end{aligned}
$$

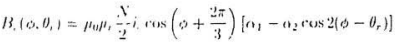

If the andur wioling is assumed to be sinusoidally distributeml, then the rotor magnetumutive forec can lot exptesseal as

$$
M, H F_{j}=-N_{j}, \sin s_{r}
$$

where $v_{f}$ is the untuber uf turns in equivalent simusodally tistributed winding and if

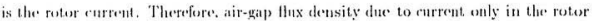
ran lue expressed in a similar way as the nurrent in stator winding and is given by

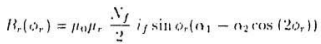

The flux linkage of a single turn of statur winding. locatcel o angle apart from a axis ant whust span letugh is a radian is given lg̣

$$
\omega\left(\omega, \theta_{r}\right)=\int_{0}^{\infty+\pi} B\left(\zeta, \theta_{r}\right) r l d \zeta
$$

where $l$ is the axial length of air gaje of the machine, $r$ is the mon madius of air gap ame $\dot{c}$ is a dummy variable. Suw the thax linkage in phase a dne to courrent only through this wimling becomes:

$$
I_{t a}=L_{1} i_{1}+\int V_{n}(0) \mathbf{W}(0,0) d 0
$$


Therefore. substituting equation $(3.2-2)$ in $(3.23)$. one ohtains

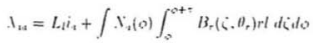

where $L_{l}$ is the stator leaknge induetance dine to leakage flux at the enel turus. Now with the value of $V_{4}$ and $B,\left(0 . \theta_{F}\right)$ of equations (3.7). (3.10) and $(3.17)$ the r.xprosisu for $\lambda_{n z}$ becomes

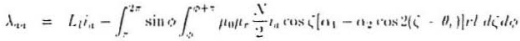

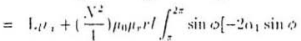

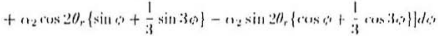

$$
\begin{aligned}
& =l_{1} i_{1}+\frac{\gamma^{2}}{1} \pi \mu_{1} \mu_{r} r l\left(n_{1}-\frac{12}{2} \cos 2 \theta_{r}\right) i_{\text {. }}
\end{aligned}
$$

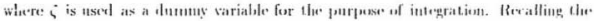

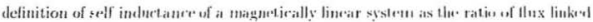
hy a wigding to the courrent flowing in that wiuling with the absence of all other winding currents. the self induetanec of $a$ wineling is givon as

$$
\begin{aligned}
& L_{w+4}=\frac{\lambda_{44}}{i_{4}}
\end{aligned}
$$

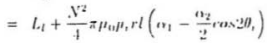

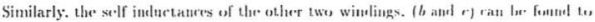
be

$$
\begin{aligned}
& L_{s_{1}}=L_{l}+\frac{V^{2}}{4} \pi \mu_{13} / \mu_{r} r l\left[r_{1}-\frac{n_{2}}{2} \operatorname{ros}^{2}\left(\theta_{r}-\frac{2 \pi}{3}\right)\right]
\end{aligned}
$$

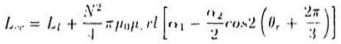

The nutual finx linkage in o winding fou 10 corrent in $b$ winding is found in in similat

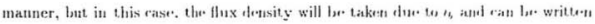


as

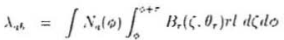

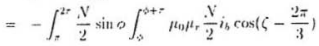

$$
\begin{aligned}
& {\left[n_{1}-n_{2} \cos 2\left(\zeta-\theta_{r}\right)\right] u l d i d \theta^{2}} \\
& =-\frac{N^{2}}{1} \frac{\pi}{2} \mu_{t_{1}} \mu_{r} r l\left[\omega_{1}+\omega_{2} \cos 2\left(\theta_{r}-\frac{\pi}{3}\right)\right] i_{r_{r}}
\end{aligned}
$$

Thus the mutual ineluctance $1 /_{36}$ can he found using

$$
\begin{aligned}
W_{u_{h}} & =\frac{\lambda_{4}}{i_{4}} \\
& =-\frac{V^{2}}{1} \frac{\pi}{2} H_{6} H_{r} r l\left[n_{1}+n_{2} \cos \cdot 2\left(\theta_{r}-\frac{\pi}{3}\right)\right]
\end{aligned}
$$

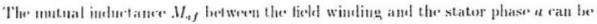
found similarly lọ:

$$
H_{1 j}=\frac{X Y_{f}}{1} \pi \mu_{11} \mu_{+} r l\left(n_{1}+\frac{n_{2}}{2}\right) \sin \theta_{r}
$$

In a like manner. Hh* mutual indurtances betwern the different windings ran be written as:

$$
\begin{aligned}
& u_{n}=-\frac{y^{2}}{4} \frac{\pi}{2} \mu_{\mathrm{a}} \mu_{r} r l\left[n_{1}+n_{2} \operatorname{ros} 2\left(\theta_{r}+\frac{\pi}{3}\right)\right] \\
& H_{h_{r}}=-\frac{X^{2}}{1} \frac{\pi}{2} \mu_{u t_{r} r l}\left[u_{1}+n_{2} \cos 2\left(\theta_{r}+\bar{r}\right)\right] \\
& M_{h S}=\frac{N N_{l}}{4} \pi \mu_{0} \mu_{r} r l\left(n_{1}+\frac{n_{2}}{2}\right) \sin \left(\theta_{r}-\frac{2 \pi}{3}\right)
\end{aligned}
$$

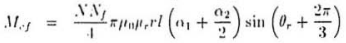

I'he stlf Ilux linkatge in the field winding an be found using

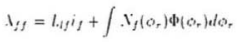




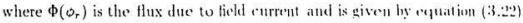

$$
\Phi\left(\omega_{r}\right)=\int_{s,}^{\omega_{n}+r} B_{r}(\zeta) r l i k
$$

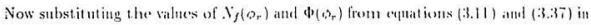
equation (3.36) onc obfains

$$
\begin{aligned}
& \lambda_{f f}=L_{t j} i_{f}+\int_{\frac{\tau}{2}}^{\frac{t_{0}}{2}} \frac{\lambda_{f}}{2} \cos \theta_{r}
\end{aligned}
$$

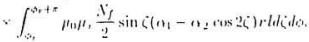

After some trigonometric manipulations and necsary integrat ions. the solf llux link age of licld winding due to the torrent itarough it, is given by

$$
\lambda_{f S}=L_{i j} i_{f}+\frac{V_{j}}{1} \pi j \mu_{\mathrm{u}} / L_{r} r l\left(n_{1}+\frac{n_{j}}{2}\right) i_{j}
$$

Therefore, the self induclance of firld winding is

$$
\begin{aligned}
& l_{f f}=\frac{\lambda_{f f}}{f_{f}}
\end{aligned}
$$

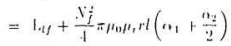

where $\mathrm{L}_{\text {if }}$ is the leakage inductance of the field wineling. The inductiones in different. phase winflings an be summarizud by defining the followiug as

$$
\begin{aligned}
& L_{A}=\frac{N^{2}}{1} \pi \mu_{1}, \mu, r l_{1} \\
& \left.l_{H}=\frac{1}{2} \frac{V^{2}}{1} \pi \mu_{t}\right) \mu_{r} r l_{1}
\end{aligned}
$$

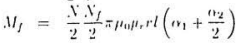

$$
\begin{aligned}
& L_{f}=\frac{V_{j}^{\prime}}{1} \pi \mu_{0} \mu_{r} r l\left(\nu_{1}+\frac{n_{2}}{2}\right)
\end{aligned}
$$

The machine inductances can now lim expressed ats

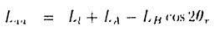




$$
\begin{aligned}
& L_{L, B}=L_{l}+L_{r}-L_{B} \cos 2\left(\theta_{r}-\frac{2 \pi}{3}\right)
\end{aligned}
$$

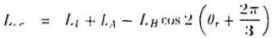

$$
\begin{aligned}
& L_{f f}=L_{l j}+L_{f} \\
& M_{n t}=-\frac{1}{2} L_{A}-L_{B} \cos 2\left(\theta_{r}-\frac{\pi}{3}\right) \\
& M_{a r}=-\frac{1}{2} L_{d}-L_{B} \cos 2\left(0_{r}+\frac{\pi}{3}\right) \\
& M_{L_{r}}=-\frac{1}{2} L_{A}-L_{B} \cos 2\left(\theta_{r}+\pi\right) \\
& H_{t} J=1 /, \sin \theta \text {. } \\
& .1 h_{s}=1 / f \sin \left(0,-\frac{2 \pi}{3}\right) \\
& u_{, s}=m_{1} \sin \left(0_{r}+\frac{2 \pi}{3}\right)
\end{aligned}
$$

Thus the there phase induetanes ran be written in matrix form as:

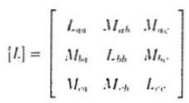

Since.

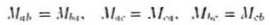

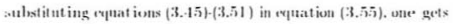




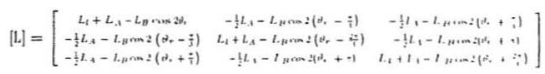

Now the flux linkage in any winding is the summation of its solf imblutanes and

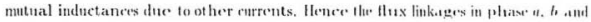
$c$ and the field are given as:

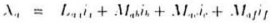

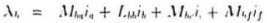

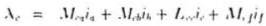

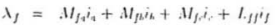

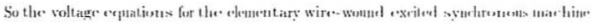
can be written as

$$
\begin{aligned}
& r_{4}=r_{4} i_{2}+\frac{d l \lambda_{4}}{d t} \\
& r_{s}=r_{b} i_{h}+\frac{d \lambda_{b}}{d l} \\
& r_{r}=r_{s} i_{c}+\frac{d d \lambda_{r}}{d l} \\
& v_{f}=r_{f} i_{f}+\frac{d \lambda_{f}}{d l}
\end{aligned}
$$

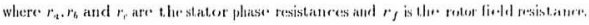

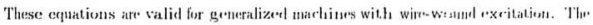
next step is to modify the above machine erguations fos a permanent magnet. syn dironous notor. 


\subsection{Machine equations for permanent magnet syn- chronous motor}

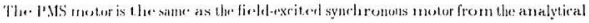
view puint. The only exception is that the rotur firlol excitation is replaced by is permanent. magne. , which gives a coustiont flux $\lambda_{M}$. Now the flux linkage in the dillerent stater phass windings due to permanent magnet rotor is given in matrix Plirm its:

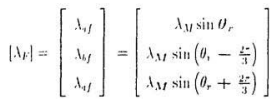

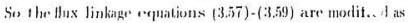

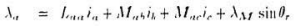

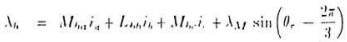

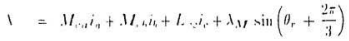

In malrix form une can write the abowe equations as

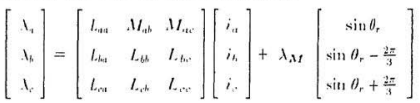

or, one cant write the alowe ergution in a more compart way as:

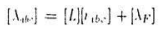

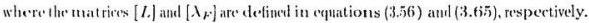
Sim, the sollage erpuations for the PMS machine can be written as:

$$
\because=r_{s} i_{t}+\frac{d \lambda_{t}}{d t}
$$




$$
\begin{aligned}
& v_{n}=m_{n} i_{b}+\frac{d . t_{n}}{d t} \\
& r_{d}=r_{i+}+\frac{d t}{d t}
\end{aligned}
$$

or in matrix form

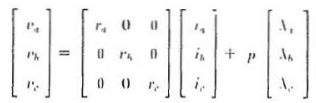

One can write the aluse enuation in compace form as:

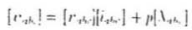

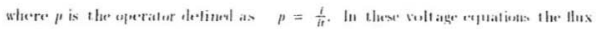

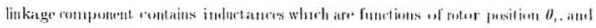

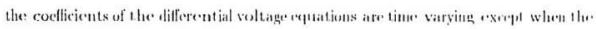

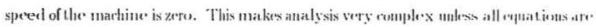

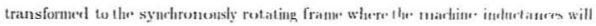

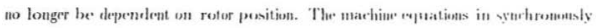
rotatimg frame are known as Park s ceplation.

\subsection{Transformation of machine equations in syn- chronously rotating frame-Park's equations}

\subsubsection{General equations on transformation}

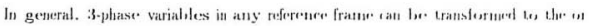
thogonal components by the following relationship [3s]:

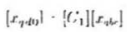


whrere.

$$
\left[x_{v t u}\right]=\left[\begin{array}{l}
s_{7} \\
x_{t} \\
x_{11}
\end{array}\right]
$$

is the orthegenal components matrix transformed from thee phase variables ant

$$
\left[s_{1} b_{0}\right]=\left[\begin{array}{l}
x_{a} \\
s_{b} \\
s_{c}
\end{array}\right]
$$

is the matrix for three phase sarialiles in any reference frane and

$$
\left[(i]=\frac{z}{3}\left[\begin{array}{ccc}
\cos \theta & \cos \left(\theta-\frac{2 \pi}{3}\right) & \cos \left(\theta+\frac{2 z}{3}\right) \\
\sin \theta & \sin \left(\theta-\frac{2 z}{3}\right) & \sin \left(\theta+\frac{2 z}{3}\right) \\
\frac{1}{2} & \frac{1}{2} & \frac{1}{2}
\end{array}\right]\right.
$$

is the rovellicion matrix of tratusformation, where

$$
\theta=\int_{11}^{t} \omega(\eta) d \eta+\theta(0)
$$

Ilere $\eta$ is the dummy variable of integration and $\theta(\theta)$ is the angle diference between axes of transformation at $t=0$ and $\omega$ is the speed of the transformed axis. The inverse of $\left({ }^{*}\right.$ is given by the follewing equation:

$$
\left[c_{i}\right]^{-1}=\left[\begin{array}{ccc}
\cos \theta & \sin \theta & 1 \\
\cos \left(\theta-\frac{2 \pi}{3}\right) & \sin \left(\theta-\frac{2 \pi}{3}\right) & 1 \\
\cos \left(\theta+\frac{2 \pi}{3}\right) & \sin \left(\theta+\frac{2 \pi}{3}\right) & 1
\end{array}\right]
$$

In ecpuations (3.76)-(3.78), $x$ can represent atuy bariable such as voluge, current or fiux linkage. 


\subsubsection{Park's Equations}

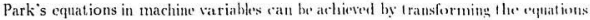
of the stationary axis to a synctoronously rotating frame axis. Startind with the

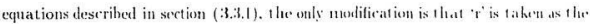
superseript or subseripts with the variables te represent that the transenmation is

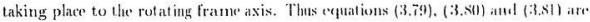
modified as follows:

$$
\begin{aligned}
& \mid(\dot{\theta}:)=\frac{2}{3}\left[\begin{array}{ccc}
\cos \theta_{r} & \cos \left(\theta_{r}-\frac{2 \pi}{3}\right) & \operatorname{cis}\left(\theta_{r}+\frac{2 \pi}{3}\right) \\
\sin \theta_{r} & \sin \left(\theta_{r}-\frac{2 \pi}{3}\right) & \sin \left(\theta_{r}+\frac{2 \pi}{1}\right) \\
\frac{1}{2} & \frac{1}{2} & !
\end{array}\right] \\
& n_{r}=\int_{11}^{\prime} \omega_{r}(\eta) d y+\theta_{r}(0)
\end{aligned}
$$

and the inverse of the above matrix can be fimmel as:

$$
\left[r_{2}^{\prime}\right]^{-1}=\left[\begin{array}{ccc}
\cos \theta \theta_{0} & \sin \theta_{r} & 1 \\
\cos \left(\theta_{r}-\frac{2 \pi}{i}\right) & \sin \left(\theta_{r}-\frac{2 \pi}{i}\right) & 1 \\
\cos \left(\theta_{2}+\frac{2 \pi}{3}\right) & \sin \left(\theta_{2}+\frac{2 \pi}{i}\right) & 1
\end{array}\right]
$$

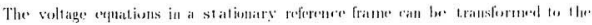
orthogonal components of at rotating referenore frame as:

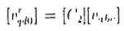

Now substituting equation (3.75) in erfuation (3. Ni5) yiedsts

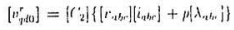

But since it can be writum that

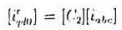




$$
\begin{aligned}
& {\left[\lambda_{2 b}\right]=\left[C_{2}\right]^{-1}\left[i_{v d u}^{r}\right]} \\
& {\left[\lambda_{a_{b} b r}\right]=\left[C_{2}\right]^{-1}\left[\lambda_{v d o}^{r}\right]}
\end{aligned}
$$

Sulatituting refuation $(3.87)$ and $(3.89)$ in (3.86) one gets.

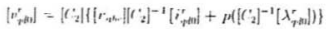

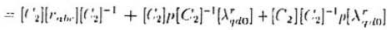

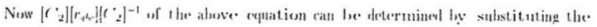
values of $\left[C^{\prime}:\right] \cdot\left|r_{*}\right|$ and $\left[r_{2}^{\prime}\right]^{-1}$ is:

$\left|r_{2}\left\|r_{4} b_{t}\right\| r^{\prime-1}\right|^{-1}=$

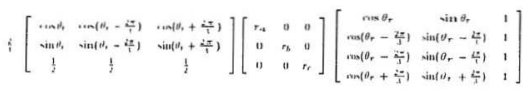

The evaluation of the above mat rives yielels

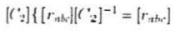

The serond term of equation (3.90) ran be eraluated as

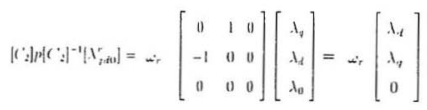


Equation (3.93) an he also he writen as

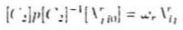

and since

$$
\left[f^{\prime}:\left[\ell^{\prime}:\right]^{-1}=1\right.
$$

The last term of cyuntimn (3.90) bevencts

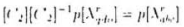

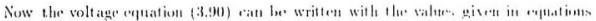
$(3.92)-(3.9 .5)$ is:

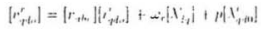

or

$$
\left[\begin{array}{l}
r_{7}^{r} \\
v_{d}^{r} \\
v_{0}^{r}
\end{array}\right]=\left[\begin{array}{lll}
r_{4} & 0 & 0 \\
\vdots & r_{k} & 0 \\
0 & 0 & r_{r}
\end{array}\right]\left[\begin{array}{c}
i_{i}^{r} \\
i_{d}^{r} \\
i_{i j}^{r}
\end{array}\right]+\omega_{r}\left[\begin{array}{c}
x_{i} \\
x_{j} \\
0
\end{array}\right]+p\left[\begin{array}{c}
x_{i} \\
x_{i} \\
x_{i j}
\end{array}\right]
$$

If it is assumeel that stator rexistance in erarli phase is equal. i...

$$
r_{4}=r_{1}=r_{2}=r_{\text {、 }}
$$

then from equation (3.97) it can bev writen that

$$
\begin{aligned}
& v_{y}^{r}=r_{v}^{\prime}+\omega_{1} \lambda_{i}^{\prime}+\mu \lambda_{1}^{\prime} \\
& r_{i}^{\prime}=r_{s} r_{i}^{\prime}+\dot{s}_{-} \lambda_{y}^{\prime}+p \lambda_{i}^{\prime} \\
& r_{1}^{\prime}=r_{s} t_{t i}+\mu \lambda_{i j}^{\prime}
\end{aligned}
$$




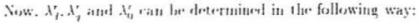

Fom eqpation $(3.70)$. is ran bo written that

$$
\left[\lambda_{1}+\alpha\right]=[L][i, k]+\left[\lambda_{F}\right]
$$

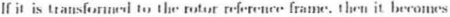

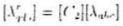

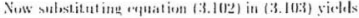

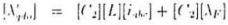

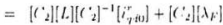

The first torm of expation (3.103) is evaluated ly putting the values of [ $\left.C_{2}\right] .[L]$

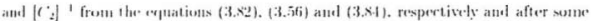

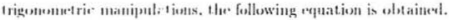

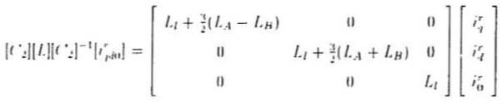

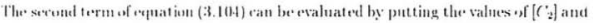
[1.1 frum equat iuns (3.82) and (3.tii) respectively: Again, after sot manipulations, oter gets

$$
[\because]\left[\mid I_{H}\right]=I_{M}\left[\begin{array}{c}
0 \\
\frac{1}{2} \\
0
\end{array}\right]=I_{M}\left[\begin{array}{l}
0 \\
1 \\
0
\end{array}\right]
$$




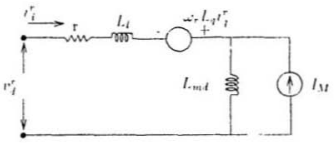

(a)

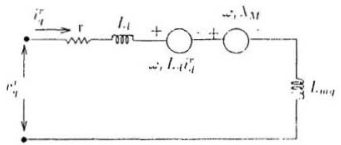

$(1$,

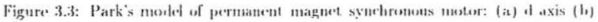
q-axis

Now defining the magnetizing induetanes in ceyuation (3.105) as

$$
\begin{aligned}
& \frac{3}{2}\left(I_{H_{A}}-L_{H}\right)=I_{\text {my }} \\
& \frac{3}{2}\left(I_{H}+L_{H}\right)=I_{m I}
\end{aligned}
$$

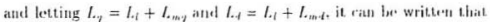

$$
\left[\begin{array}{l}
\lambda_{y}^{r} \\
\lambda_{i}^{r} \\
\lambda_{i j}^{r}
\end{array}\right]=\left[\begin{array}{lll}
L_{2} & 0 & 0 \\
0 & L_{i f} & 0 \\
0 & 0 & L_{1}
\end{array}\right]\left[\begin{array}{l}
i_{1}^{r} \\
i_{i t}^{r} \\
i_{i j}^{r}
\end{array}\right]+\lambda_{M}\left[\begin{array}{l}
0 \\
1 \\
0
\end{array}\right]
$$

Therefore.

$$
\lambda_{y}^{\prime}=L_{,} i_{i}^{\prime}
$$




$$
\begin{aligned}
& \lambda_{1}^{r}=l_{-i_{i}}^{r}+\lambda_{y} \\
& x_{11}^{\prime}=l_{-i} i_{n}^{r}
\end{aligned}
$$

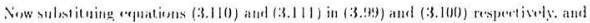

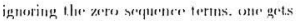

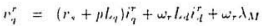

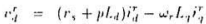

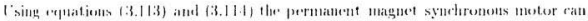

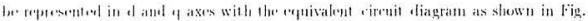
3.3 .

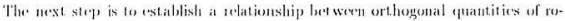
tiating atul slat ionary reference fratues.

\subsubsection{Relationship between orthogonal quantities of sta- tionary reference frame and synchronously rotating reference frame}

Relationshipe san be astablished betwern quadrature and direet axis variables of the stationary reference fiame and the rotating reference frame by the following equation:

$$
\left[x_{1+10}^{+}\right]=\left[( { } ^ { * } ) \left[x^{4}+t u\right.\right.
$$

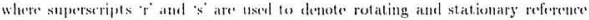
frame "fuantities. respectively. $\left[C_{-}\right]$is the coeflicient matrix which ran be evaluated is follows:

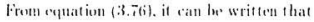

$$
\left|r_{i+1}^{*}\right|=\left[c_{i}\right]\left[r_{t, n}\right]
$$


Substituting equation (3.116) into (3.115), ont g.1s

$$
\left[x_{i, n}^{*}\right]=\left[r_{i}\right][[;][\mid x, k]
$$

Again following the relation of typation (3.55), it ran he written as

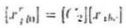

Thus conparing equation (3.117) and (3.11s), it can bu. wrillen th.t

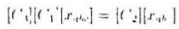

from which

$$
[r s]=\left[c_{2}\right]\left[c_{1}\right]^{-1}
$$

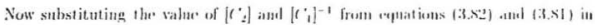
(3.120) one gets.

$$
\left[r_{x}\right]=\left[\begin{array}{ccc}
\cos \left(\theta_{r}\right) & -\sin \left(\theta \theta_{r}\right) & \| \\
\sin \left(\theta_{r}\right) & \cos \left(\theta_{r}\right) & 0 \\
11 & 0 & 1
\end{array}\right]
$$

From equation $(3.115)$ it can ln. written that

$$
\left[r_{i d i t}^{*}\right]=\left[r_{i}\right]^{-1}\left[r_{y, i t}^{\prime}\right.
$$

and

$$
\left[\left(c_{3}\right]^{-1}=\left[C_{3}\right]^{r}\right.
$$

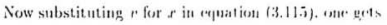

$$
\left.\mid r_{i+1}^{\prime}\right]=\left[r \cdot i\left[r_{i+1}^{\prime}\right]\right.
$$




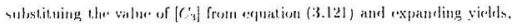

$$
\begin{aligned}
& r_{r}^{r}=r_{r} \cos \theta_{r}-r_{i}^{s} \sin \theta_{r} \\
& r_{i}^{\prime}=r_{j} \sin \theta_{r}+m_{i}^{s} \cos \theta_{r}
\end{aligned}
$$

where zero sipluence tertus are ignereed. Sinilarly. using equations (3.122) and (3.123)

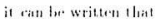

$$
\left[r_{r t+1}^{*}\right]=[r]^{-1}\left[r_{r d t}^{\top}\right]
$$

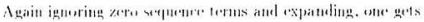

$$
\begin{aligned}
& r_{r}=r_{r}^{r} \cos \theta_{r}+r_{d} \sin \theta_{r} \\
& r_{i}=r_{r}^{r} \cos \theta_{r}-r_{r}^{r} \sin \theta_{r}
\end{aligned}
$$

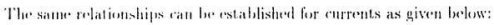

$$
\begin{aligned}
& i_{t}=i_{1} \cos \theta_{r}-i_{t}^{3} \sin \theta_{r} \\
& i_{i}=i_{i} \sin \theta_{r}+i_{i} \cos \theta_{r} \\
& r_{i}=r_{1} \cos \theta \theta_{r}+i_{t} \sin \theta_{r} \\
& i_{d}^{s}=i_{d}^{r} \cos \theta_{*}-i_{y} \sin \theta_{r}
\end{aligned}
$$

where $\theta_{n}$ is defincel proviunsly is

$$
\theta_{r}=\int_{11}^{\prime} \omega_{r}(f)+\theta_{r}(0)
$$

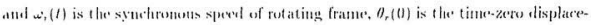
ment of retating frame quadrat ure axis with respeet to ruatrature axis of stationary frame. i.e. "a axis of three phase voltages as shown in Fig. 3.4.

The next step is torstiblish a relation lectween direct and quarlrature axes quantities and flores phase quantities, so that the algoritlum can be used to ubtain rotur position and sperd information with masured stator boltages and currents. 


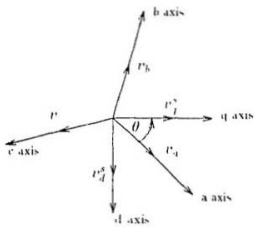

(a)

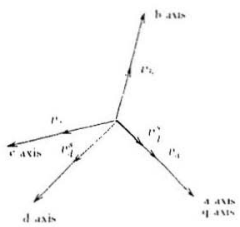

$\{$ l,

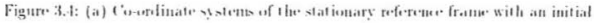
0. (b) ('usortinate ssstems of slat ionary reforence frame with $\theta=0$.

\subsubsection{Relationship between three-phase and or thogonal quan- tities in stationary reference frame}

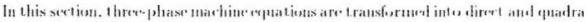
ture axis on the sime stationary reference frame. Sis equations (:3. 76 (i) (3.79) ran lu. used for this analysis. Here the value of $\theta$ in mpuation (3.s0) is evalualeat as follows:

$$
\theta=\int_{n}^{t} \omega(t)+\theta(0)
$$

It has been alreaty mentioneri that 2 is the speri of the transoumerl frame. ant

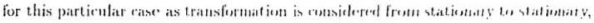

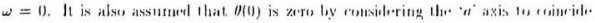

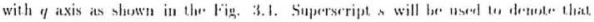
transformation is taking plare betwon stationary w statinary frane. Sulntituting. 


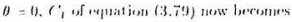

$$
\left|r_{i}\right|=\frac{2}{3}\left[\begin{array}{ccc}
1 & -\frac{1}{2} & -\frac{1}{2} \\
0 & -\frac{4}{2} & \frac{4}{2} \\
\frac{1}{2} & \frac{1}{2} & \frac{1}{2}
\end{array}\right]
$$

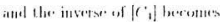

$$
\left|V_{1}\right|^{-1}=\left[\begin{array}{ccc}
1 & 0 & 1 \\
-\frac{1}{2} & -\frac{\sqrt{4}}{2} & 1 \\
-\frac{1}{2} & \frac{21}{2} & 1
\end{array}\right]
$$

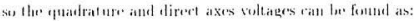

$$
\left[r_{i n}^{*}\right]=\left[C_{i}^{\prime}\right]\left[r_{a}, \ldots\right]
$$

from which

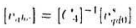

Substituting aquations $(3.136)$ and $(3.137)$ in equations $(3.135)$ and $(3.139)$ and ex-

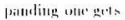

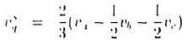

$$
\begin{aligned}
& =\frac{2}{3} r+\frac{1}{3} v-\frac{1}{3} v
\end{aligned}
$$

lont sines $n_{n}+r_{n}+r=0$, it ean be writsen that

$$
\frac{1}{3} r_{1}=-\frac{1}{3} n_{2}-\frac{1}{3} r_{6}
$$

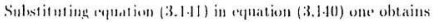

$$
r_{1}^{*}=\frac{2}{3} r_{14}+\frac{1}{3} r_{4}=r_{4}
$$


and

$$
\begin{aligned}
v_{i} & =\frac{2}{3}\left(-\frac{v \sqrt{3}}{2} r_{4}+\frac{v \overline{3}}{2} r_{1}\right) \\
& =-\frac{1}{v^{3}} r_{4}+\frac{1}{v^{3}} r .
\end{aligned}
$$

Inversily:

$$
\begin{aligned}
& r_{4}=r_{i}^{*} \\
& r_{4}=-\frac{1}{2} r_{i}^{2}-\frac{\sqrt{3}}{2} r_{i} \\
& r=-\frac{1}{2} r_{i}+\frac{\sqrt{3}}{2} r_{i}
\end{aligned}
$$

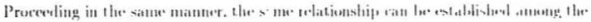

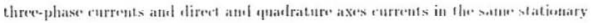
france which is given as:

$$
\begin{aligned}
& i_{i}=i_{+} \\
& i=-\frac{1}{\sqrt{3}} i+\frac{1}{\sqrt{3}} i
\end{aligned}
$$

Inversely

$$
\begin{aligned}
& i_{4}=i_{i} \\
& i_{1}=-\frac{1}{2} i_{i}-\frac{\sqrt{3}}{2} i_{i} \\
& i_{1}=-\frac{1}{2} i_{i}+\frac{\sqrt{3}}{2} i
\end{aligned}
$$




\subsection{Rotor-speed and rotor-position in terms of stator currents and voltage}

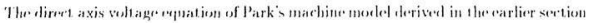
is given is

$$
n_{d}^{r}=\left(r_{*}+p L_{i l}\right) i_{d}^{3}-\omega_{r} L_{y_{i}} j_{n}^{r}
$$

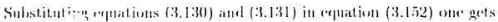

$$
\begin{aligned}
& r_{d}^{\prime}=\left(r_{s}+p l_{a}\right)\left(i_{i} \sin \theta_{r}+i_{j} \cos \theta_{r}\right)+ \\
& \omega, l_{n, 2}\left(i ;, \cos \theta \theta_{r}-i_{i} \sin \theta \theta_{r}\right.
\end{aligned}
$$

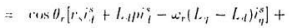

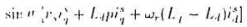

Now putuing cofuation $(3.126)$ in $(3.153)$ one gets

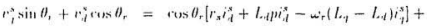

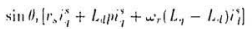

()r.

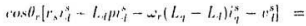

$$
\begin{aligned}
& \sin \theta_{r}\left[u_{i}^{s}-r_{s} i_{i}^{s}-L_{r} p_{i}^{* x}-\omega_{r}\left(L_{q}-L_{r}\right) i_{i}^{*}\right]
\end{aligned}
$$

Therefore

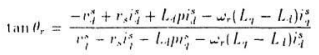

$(1)$

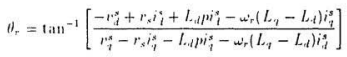




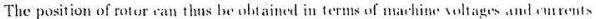

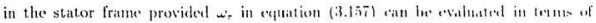

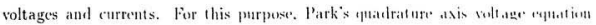
(3.113) is used. Foun this equation it ran he wriften that

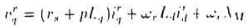

Substituting equations (3.130) and $(3.131)$ in (3.158), the folluwing cquatum ate obtainewl:

$$
\begin{aligned}
& r_{\gamma}^{r}=\left(r_{8}+\mu L_{\gamma}\right)\left(i_{1}^{*} \cos \theta_{r}-i_{i}^{*} \sin \theta_{r}\right)+ \\
& \omega_{r} L_{A}\left(i_{i n}^{n} \sin \theta_{r}+i_{f} \cos \theta_{r}\right)+u_{i} I_{M}
\end{aligned}
$$

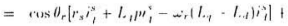

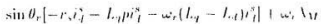

Substituting repuation $(3.125)$ in $(3.179)$. one oblains

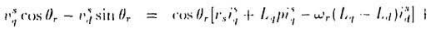

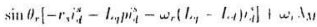

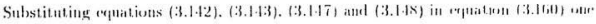
oblains

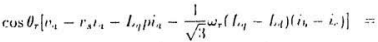

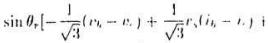

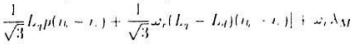


()r,

$$
\begin{aligned}
& \frac{\omega_{r} \lambda_{M}}{\cos \theta}=
\end{aligned}
$$

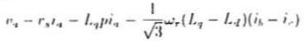

$$
\begin{aligned}
& -\tan \theta_{r}\left[-\frac{1}{\sqrt{3}}\left(m_{h}-r_{-}\right)+\frac{1}{\sqrt{3}} r_{s}\left(i_{s}-i_{r}\right)+\frac{1}{\sqrt{3}} L_{+} p\left(i_{s}-i_{-}\right)+\right.
\end{aligned}
$$

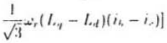

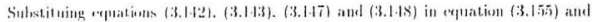
issเuminL

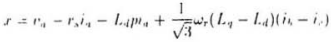

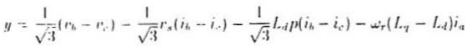

onc* ohth ains

$$
\begin{aligned}
& \tan \theta_{r}=\frac{y}{x} \\
& \sin \theta_{r}=\frac{x}{z}
\end{aligned}
$$

where

$$
z=\sqrt{\left(r^{2}+y^{2}\right)}
$$

The expression for, an be simplified by taking equal value for $L_{y}$ and $L_{\text {. }}$ which rath i.e axsumed as [31]

$$
L_{s}=\frac{\left(L_{\eta}+L_{i d}\right)}{2}
$$




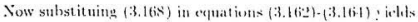

$$
\begin{aligned}
& \frac{\omega_{r} \cdot \lambda_{1}}{\cos \theta_{r}}=
\end{aligned}
$$

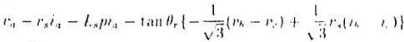

$$
\begin{aligned}
& +\frac{1}{\sqrt{3}} l_{s} p\left(i_{b}-i_{i}\right) \\
& x^{\prime}=n_{1}-r_{1} i_{4}-l_{1} m_{1}
\end{aligned}
$$

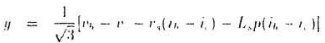

Therefore from equat ins $(3.153)$. it an be writlen this

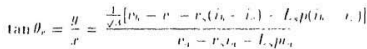

$$
\begin{aligned}
& \therefore \omega \theta_{r}=\frac{r}{\sqrt{\left(r^{2}+\eta^{2}\right)}}=
\end{aligned}
$$

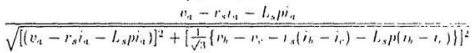

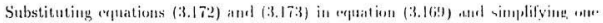
gets

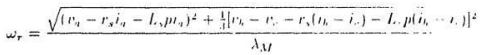

The rotor position 0, ran be found by sulstituing the value of $w$, in He. following. equation:

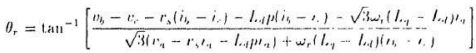


Thus lrom andiation (3.174) and (3.175), one obtains

$$
\eta_{r}=\operatorname{tin1}^{-1}\left[\frac{d}{B}\right]
$$

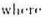

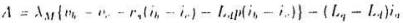

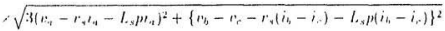

inirl

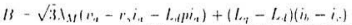

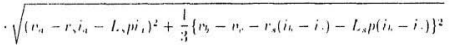

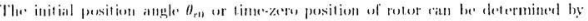

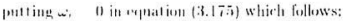

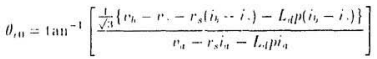

\subsection{Summary}

In this diapter. expressions for the rotor sperd and rotor pesition in terms of stator

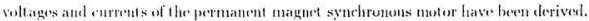

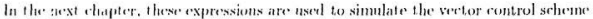

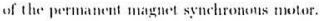




\section{Chapter 4}

\section{Simulation of position sensorless}

\section{permanent magnet synchronous motor drive}

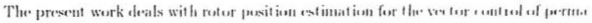

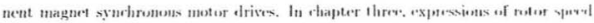

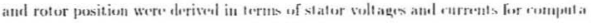
tional purposes. In this chapler. computer simulat ion of drive systems are provider for the following ronligurations:

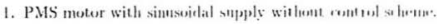

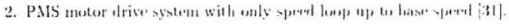

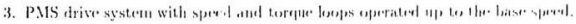

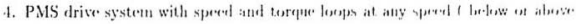
the batse speerel). 


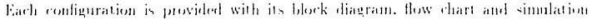
in:sulis.

\subsection{Simulation of permanent magnet synchronous motor with sinusoidal supply without control scheme.}

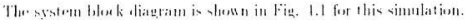

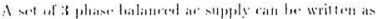

$$
\begin{aligned}
& r_{t}=I_{\text {in }} \cos u^{\prime} \\
& r_{1}=1_{\text {in }} \cos \left(-\frac{2 \pi}{3}\right) \\
& r=1_{n} \cos \left(\omega t+\frac{2 \pi}{3}\right)
\end{aligned}
$$

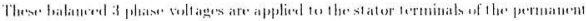

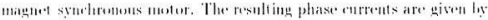

$$
\begin{aligned}
i_{1} & =\ln \cos (\omega t-i) \\
1_{1} & =l_{n} \cos \left(\omega t-\frac{2 \pi}{3}-i\right) \\
1 & =1 . \cos \left(\omega t+\frac{2 \pi}{3}-i\right)
\end{aligned}
$$

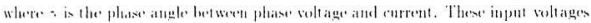

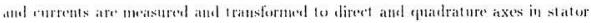

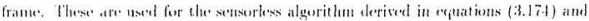

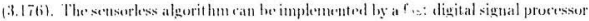

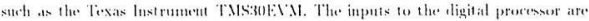




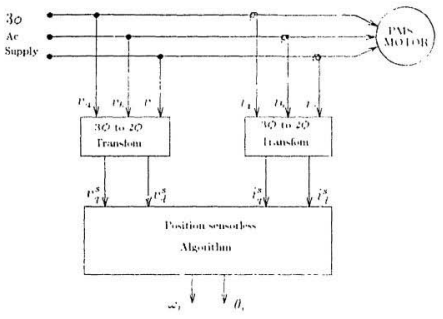

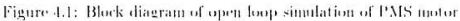

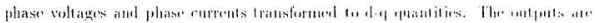

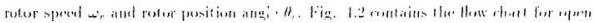

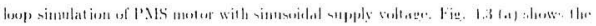

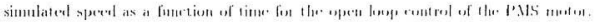

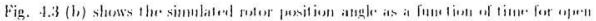
loup iontrol rise. 


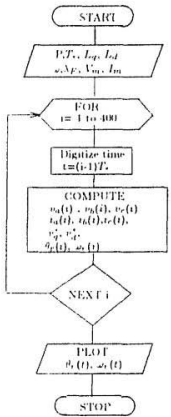

Figure 1.2: Flow chart for open lowp simnlation of P'MS notur 


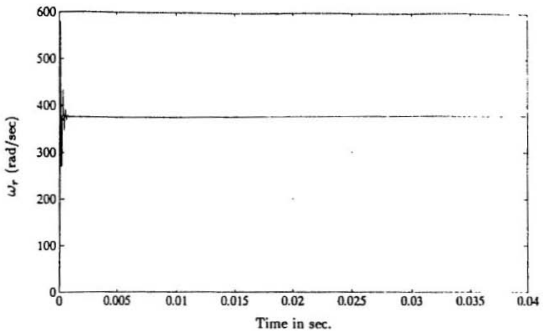

(a)

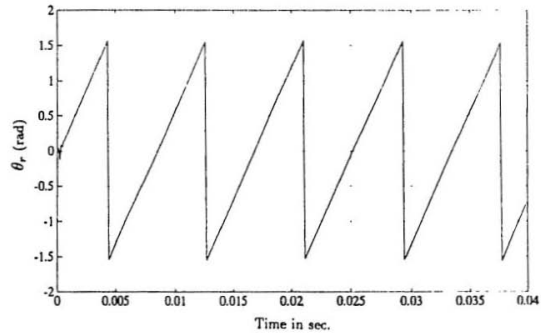

(b)

Figure 4.3: Open lesp simulation of PMS motor. (a) Rotor spered. (b) Rotor pexitien angle. 


\subsection{Simulation of closed loop vector control of permanent magnet synchronous motor}

As mentimest antlier. He PMS motor an be controlled veretorically when the stator

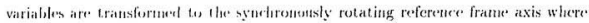
the simusodal quantitios appecit is de quantities. So from the concept of the motor control, the developeel torgune $T$, can be expressed as

$$
T_{i}^{\prime}=h_{i} I_{i} I_{f}
$$

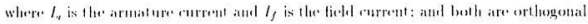

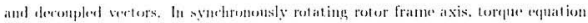
$(+1.7)$ can lie written ats

$$
T_{i}=r_{i} i_{i}^{r} I_{j}
$$

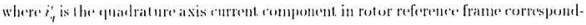

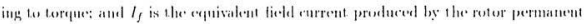

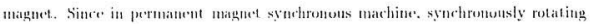

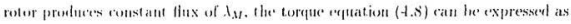

$$
r_{*}=\kappa_{m} i_{i} \lambda_{M}
$$

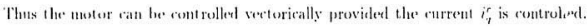

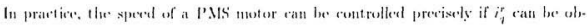

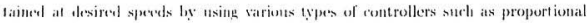
(f'). propurtissal interal (I'l) or pruportional integral dilforential (PID) controllers. The current $i_{\text {; }}$ cin bu used to drive an imerter to operate a motor at different sperels. Before guing iute furdher details of cout rol aspects, the relation between the prak 


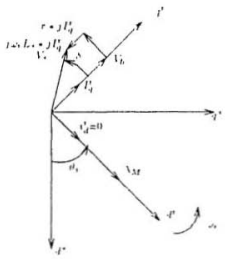

Fing (:1)

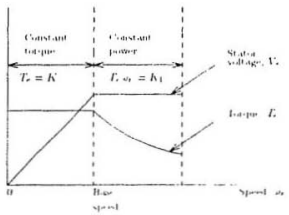

Fig. (b)

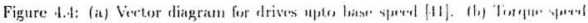
characterislius. 
value of the applicel seltage and the $i^{r}$ is established first with the help of the vector diagram. In the wetur diagram of Fig. $4.4(a), \lambda_{M}$ is shown on the direct axis of the motating frame. If nece, the lask onf produced will be on the quadrature axis and is given ly

$$
V_{h}=\frac{j \omega_{r} \lambda_{M}}{r_{1}}
$$

where $c_{1}$ is it renstint, the value of which is given by 1.5 [41]. Thus from sector diagran of Fig. 1.11 it), the appliod voltage is given by

$$
l_{i}=I_{i}+\left(v+j w_{i} L_{s}\right) j I_{7}^{r}
$$

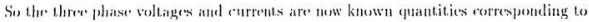
a desiend speed of the motor. Thene known quantities are ased in the simulation of the drive systertu.

\subsubsection{PMS motor drive system upto base speed with speed feedback loop only}

This system is atpable of oprerating upto hase sperd only [31]. The tortge is matafaimed ronstant uphe the hase spert as shown in Fig. fol(b). Thus. fur this drive.

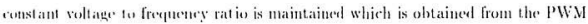
operation of the voltage sumere inverter (VSt). The feedback loup usent is only the speed. The whole driee system can be described by the following block diagram as shown in ling. 1., i. 


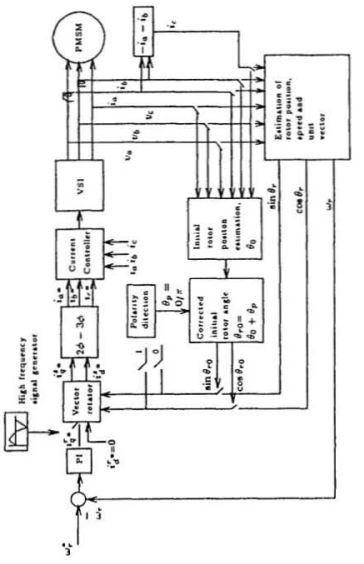

क् 
The block diagram (fig. 4.i) romsists of a number of small blucks which are Arsignal to preform sperifie functions for ihe operation of the drive. The general desrriptions and the funrtions of thene blorks are disrussed below:

\section{PI controller}

The prepert ional integral (1') controller consists of the following transfer funetion in the Laplace domain us

$$
r(s)=K_{1}+\frac{K_{2}}{s}
$$

where $K_{1}$ correspencls to the proportional part and $\frac{K_{2}}{x}$ accounts for the integral part. If the input of Ple rontroller is $Y(s)$ and the ontput is $Y^{*}(s)$, then it can be written thist

$$
\frac{I(s)}{I(s)}=h_{1}+\frac{h_{2}}{s}
$$

which rat alse lue writhen in the form

$$
s H(s)=h_{2} \cdot V(s)+h_{1} \cdot s \cdot(s)
$$

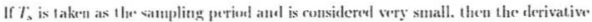
can be written in linile slifierente form as

$$
\frac{Y(u+1)-Y(i i)}{T}=h_{i} \cdot V(i i)+h_{1}\left[\frac{[Y(i i+1)-X(i i)}{T}\right]
$$

where $n, u+1$ aw the sulseruent sampling instants. Nuw equation (4.15) can be writlen as

$$
Y(i i+1)=Y(i i)+K_{2} V_{x} \cdot(i i)+K_{1} \cdot X(i i+1)-K_{1} \cdot X(i i)
$$

The actuation (1.1ti) is usid to simulate the P'l controller blocks.

'The function of the P'I cont roller used in the bleck diagram (Fig. 1.5) is to give a current conmuand from the error signal of command spered and actual speed. 


\section{Vector rotator}

This is the block which transfers the rotor reference frame quant it ie's tu stater reference frame quantities. By this block, the command output $i_{t}$ ant $\because \because$ are formulated using equations (3.130) and $(3.131)$ with commond input inrrents $r_{7}$, it, and unit vectors $\cos \theta_{r}, \sin \theta_{r}$.

\section{2 phase-3 phase transfer block}

The function of this blesk is to transfor the it-4 stither currents to the there phase stator currents. The three phase slator enrrents are uscil as referenes of the current controller as shown in Fig. 4.6.

\subsubsection{Current controller and voltage source inverter (VSI)}

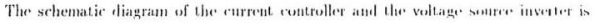

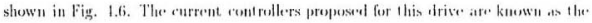

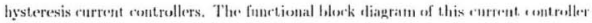

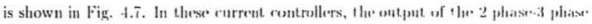
transfer bluck, the sine reference wavefurms are rompared with the artual phas. currents. The actual phase currents are allowet to vary within in prescrilned higher and

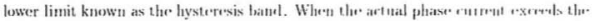
higher limit (Fig. 4.7 (b) ). the upper transistor of the fhalf briege for that part ie ulat phase is turned off and the lower one is tarneel on, giving is change of ontput voltage from the positive half of inverter de viltage to the negative half. Whera this switrhing. action occurs, the phase currents stiat deraying as sluewn in Fig. $4.7(1,1)$. A the. phase currents just rearh the lower limit of the hysteresis hated. the lowe thatisinter is turned off and the upper one is again turned on. In this pattionlat fashion. the 


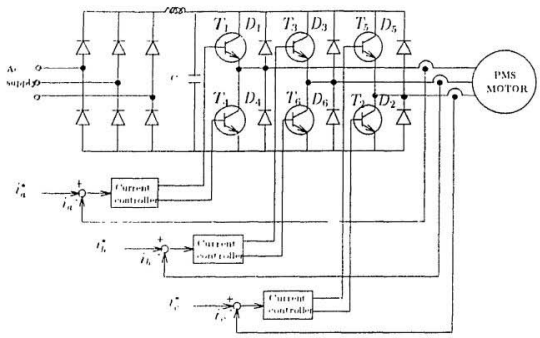

Figure l.fi: Vultage sensere inverter and corrent controller [39]

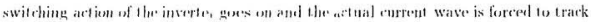
the referene wave within the hysteresis banc Because of the use of this tyge of carrent coutcoller. the phase currents are considered as simusojelal.

\section{Initial rotor position estimator block}

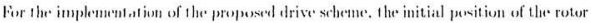

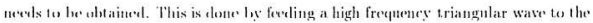

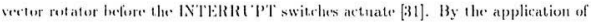
such a signal, the rotor does not nuse due to the zero average torque. Initially, the arhitraty unit verturs ase $\theta_{r}=1$. sinn $\theta_{r}=0$ are applied to the vector rotator to get the refiener signal for the current controller which drives the inserter. The output 


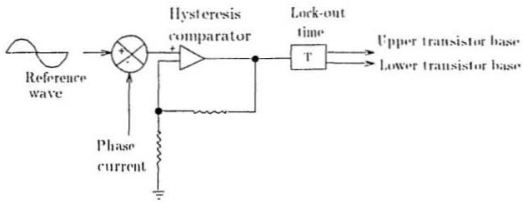

(a)
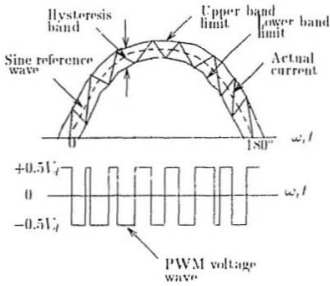

(li)

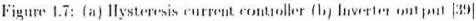


of the inverter is the PW.M voltage which is applied to the machine. This results in small pulsating motion of the rotor. By measuring phase currents and voltages. the initial rutor position $\theta_{n}$ can be estimated using equation (3.17i).

\section{Polarity detection block}

The artual initial position of the rotor is dependent on the polarity of the magnet which is in the virinity of a referme: axis of the stator. For example. if $X$ pole is in :. he virinity of phase $n$, thete the true intitial position will be

$$
\theta+0+0+0
$$

Lute if 5 pule is clese to phase a, then

$$
\theta_{11}=\pi+\theta_{0}
$$

The polarity of the magnet an loe aletermineal ly the following procedure [31]. $A$ sefuare wase is applicd to phose $t$. If $\mathrm{N}$ pole is in the vicinity of axis. then the pesitive part of the applinel voltage will aid in the magnetization and nexgative part will Ifrrease the naguetization. Hence the phase current with this voltage will be greater for the prosition part than that dhe to the negative part of the spuare wave. If the rexrse be the rase, then it can be concluded that $\mathrm{S}$ pole is close to $a$ axis. This. by following the aluse proserelure, decision is taken as to which one is added to $\theta_{0} .0$ เท.

\section{Rotor position and speed estimator}

I sing refut ions $(3.17 .1)$ atd $(3.176)$. this block outputs the speed $\omega_{\text {r }}$ and the rotor position $\theta_{1}$. One $\theta_{r}$ is known. the unu vetors $\sin \theta$, and $\cos \theta_{r}$ are generated. This bleck sarts working after the actuation of INTERRI'PT switch. 


\subsubsection{Working principle of the drive system}

The command sperd $\omega ;$; is applied to the Pl controller which oufunts the refierenes

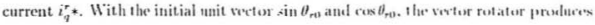
the quadrature and direvt axes referenes currents whith are Iransforned to ilereve phase sine reference currents for the input of the hysterevis curtiont nont roller. Fhe current controller drives the inverter giving PISW veltages to the mathe terminal. As the motor is starterl. the interrupt switithes are turned on and fhe estimator

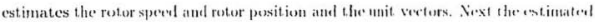

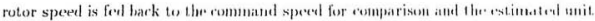
vectors are fed to the vector rolatur to generate conumand statur o urrouls.

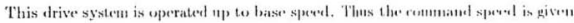

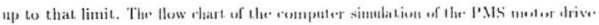
with PI controllers is given in Fig. 4.5 The sinulatiun has hara rarrierl ant with th..

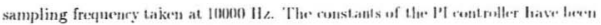
taken as $K_{1}=-0.001$ and $K_{2}=6$. 


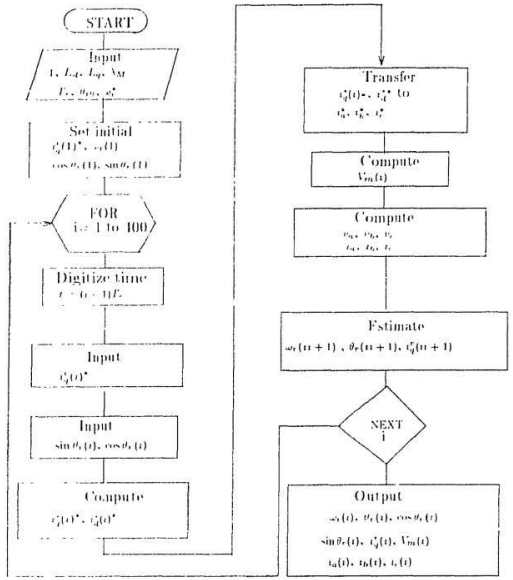

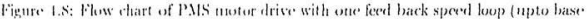
spindil. 


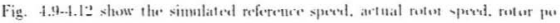

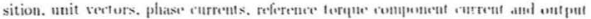

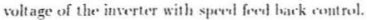




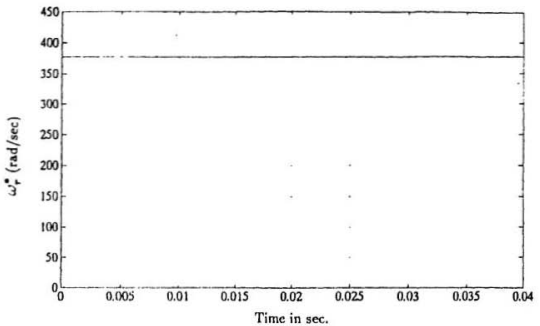

(a)

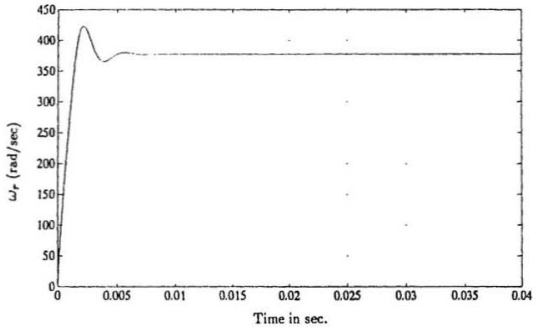

(b)

Figure 1.9: Simulation of single loop (speed loop) PMS motor drive. (a) Reference notor speed. (h) Actual notor speced. 


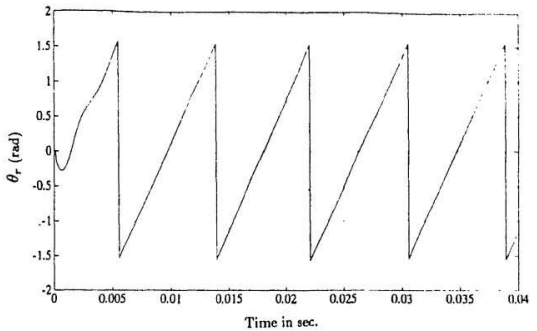

(a)

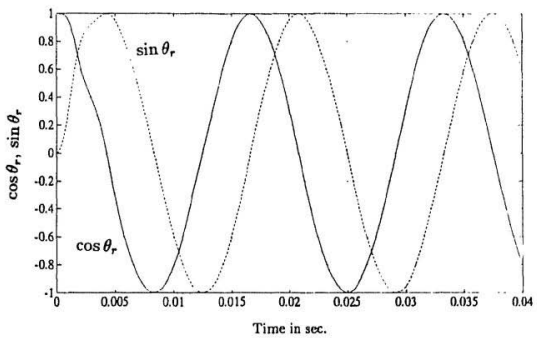

(b)

Figure 4.10: Simulation of single loop (speed loop) P.MS moter drive: (a) Hotur position (b) linit vectors. 


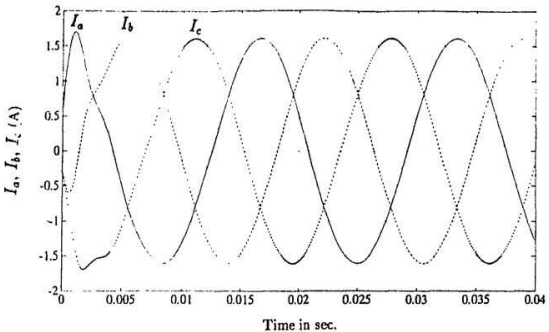

(a)

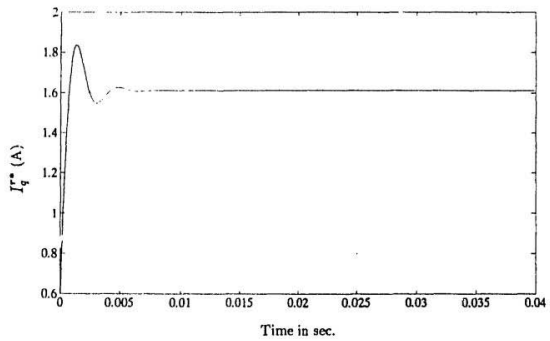

(b)

l"ignre 1.11: Simulation of single loop (speed loop) PMS motor drive. (a) Phase inrrents (b) Rerivente toreque component current 


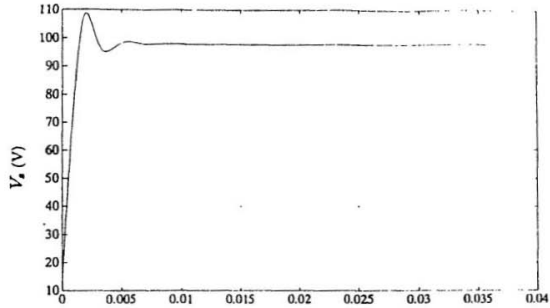

Time in scc.

ir igure 1.12: Output voltage of the inverter 


\subsection{PMS motor drive with two control loops}

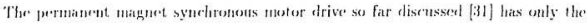
spand control liste. It. is mustable if there is a large cariation of toreme due to any

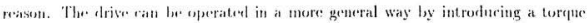

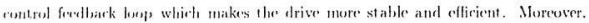
the drive respuse an ta inupoverl with the introdurtion of this additional feadback

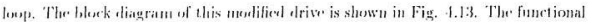

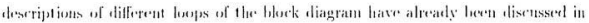

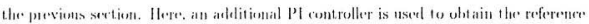

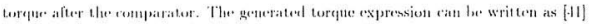

$$
\gamma_{1}=\frac{3}{2} \frac{l^{\prime}}{2} \lambda_{M} i_{r}^{r}
$$

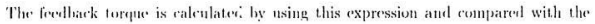

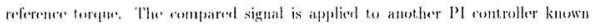

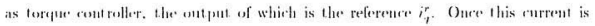
whtamest. the drise works in a similar way as the previous one. 


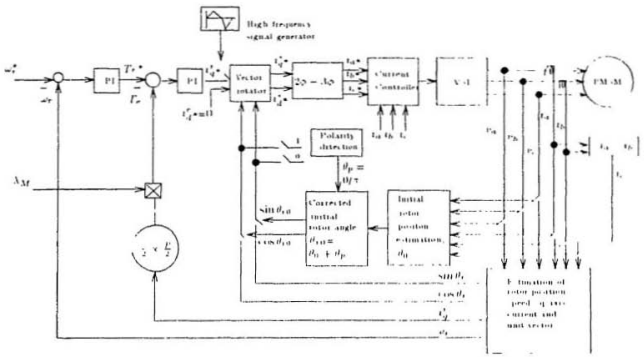

Figure 4.13: Blork diagram of PMS uol or drive system with two nutrul hnips. 
The How thart of the computer simulation of this morified drive is shown in Fig. 4.|4. Starting with input clatia and an initial speed, unit vertors and the tortue romponent carrent. the subsergent speeds. torque and unit vectors are catcolated liy the sustorless algorit!m. The estimated speed and torcue are comparcel with Lhe reference spexd and torque respertively. I'sing some PI rontrollers. the inpus of rurrent rontrollers are generated. The current controllers drive the incerter. The unerlifienl drive system is sinulated with the following constants for the PI controller: $K_{1}=0.1, K_{2}=$ inl. $K_{4}=0.05, K_{4}=200$. The sampling frequeucy is $10000 \mathrm{H} \%$ The reference speed taken for this drive simulation is the base speet. Figs, 4.15 to 1.1!) show the simulated reforence sperel. rotor speed, rotor pesition. unit vertors. phase currenss, invertur ontput voltage, reference ontput torque of the Pl controller.

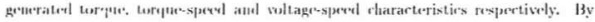
intreduring torque contrel leop in the modified ilrive, the speed response has bern impreverl as slown in Figs. 4.9 (b) and 1.15 (b), respertively. The generated torque loep is new avaibable which is absent in the previous olrive. The variation of the torque is comperasated by comparing the generated torque with reference torgue and using

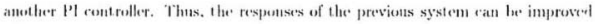
with the aldit ional cost of Pl cont rollers and comparaturs. 

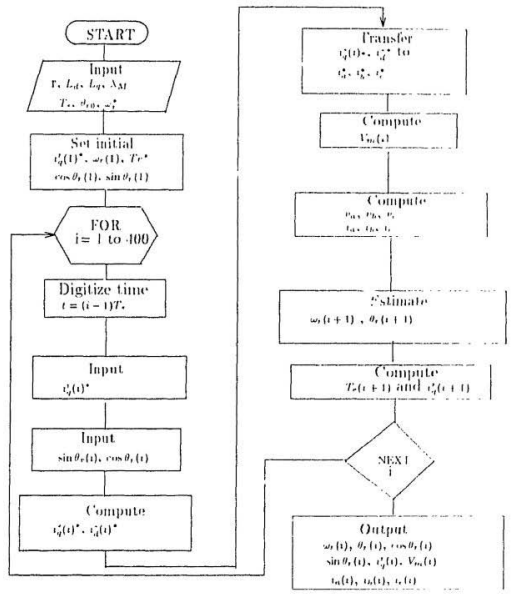

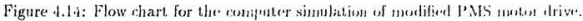




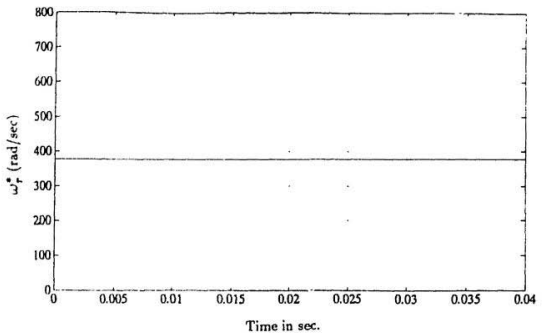

(a)

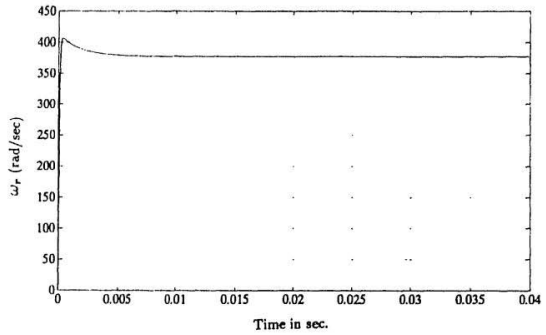

(b)

Figure 1.15: Simulation of wo-loop (speed and torque) PMS motor drive. (a) Referithe squerel. (b) . litual sperd. 


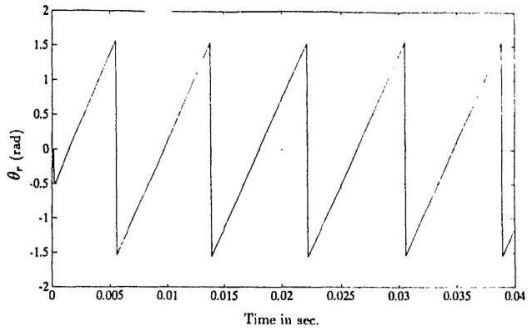

(a)

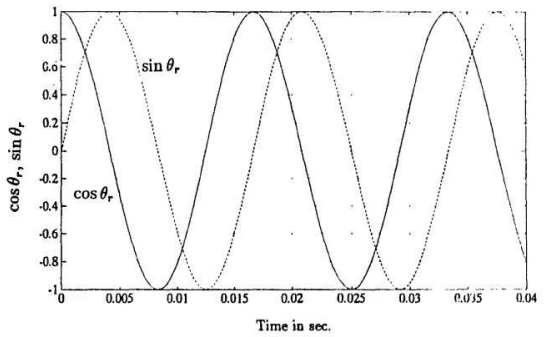

(b)

Figure 4.16: Simulation of two-loop (speed and torque) PMS moter drive. (a) Rotor position angle. (b) l'nit vectors. 


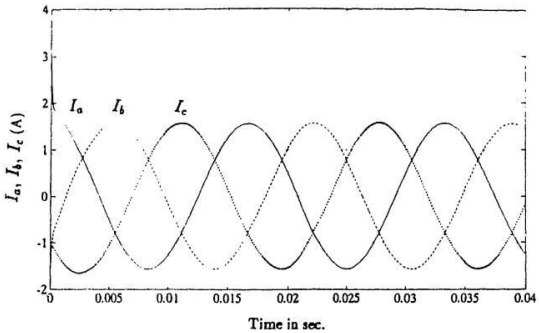

(a)

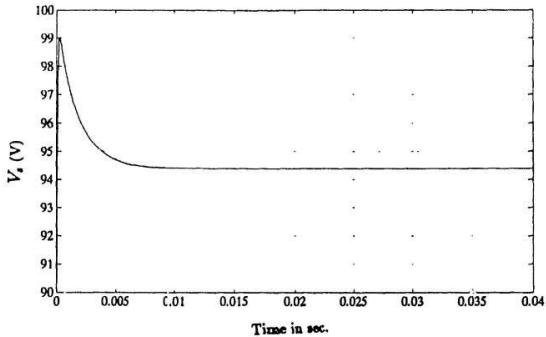

(b)

Figure 4.17: Simulation of two-loop (speed und torque) PMS motor drive. (a) Phase iurrets. (h) livirter ontput voltage. 


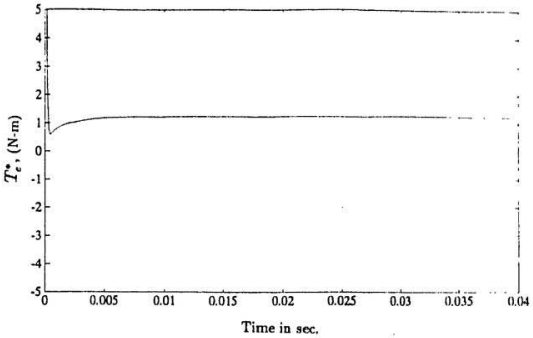

(a)

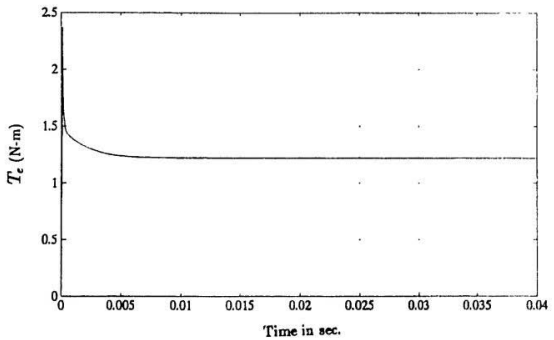

(b)

Figure 4.18: Simulation of two-loop (speed and torque) PMS motor drive. (a) Rerfrrence torque. (b) Cunerated torque. 


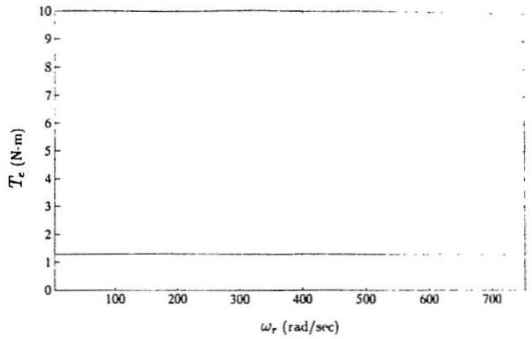

(a)

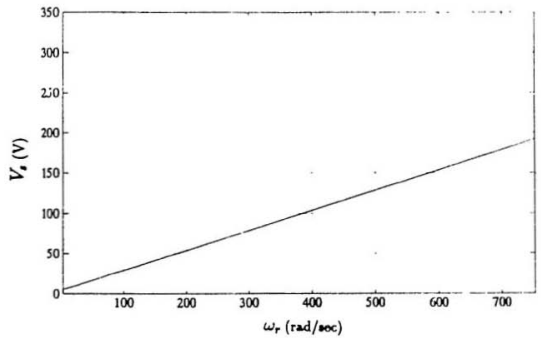

(b)

Figure 4.19: Simulation of two-loop (speed and torque:) P.MS motor drive. (a) 'Jorque: ss speed chararteristics. (b) Voltage ves speesl characteristirs. 


\subsection{PMS motor drive operation above base speed- Field weakening method}

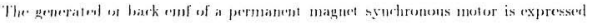
by the following atiations:

$$
V_{b}=j \omega_{r} \lambda_{M}
$$

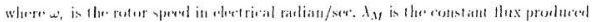

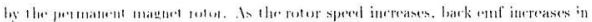

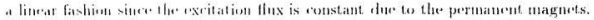

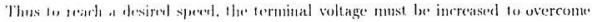
1he hack ant. This phenesterten is ofserved clearly in Fig. 1.I!). It is shown in Fig,

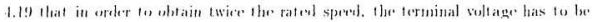

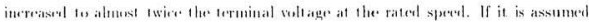

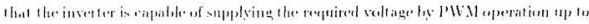

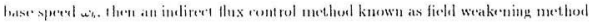
mas las applied to the Irives so I lat the terminal voltage will be cunstant after the

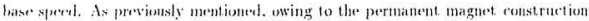
of the rotor, nuthing tan be done on the rotor side from the control puint of siow.

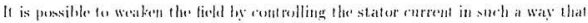
a dired axis earrent component in the rolating frame axis can be gonerated which will uppese the main liedel produced hy the permanent mignet. The position of this Anren and the fesultant trminal solt age are shown in the vector cliagram (Fig 4.20). Hewe the expression for 1 ; is motified as:

$$
l_{s}=\left(r+j_{w}, l_{s}\right) i I_{j}+j_{\omega_{r}} l_{k} l_{i}^{r}+j_{w_{r}} l_{M}
$$




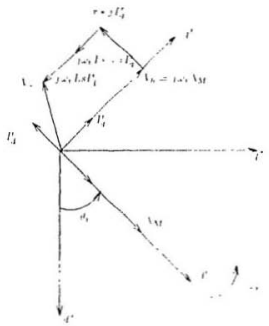

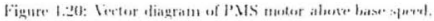

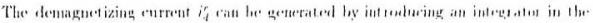

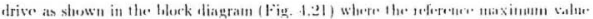

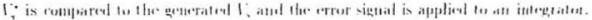

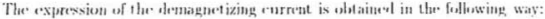




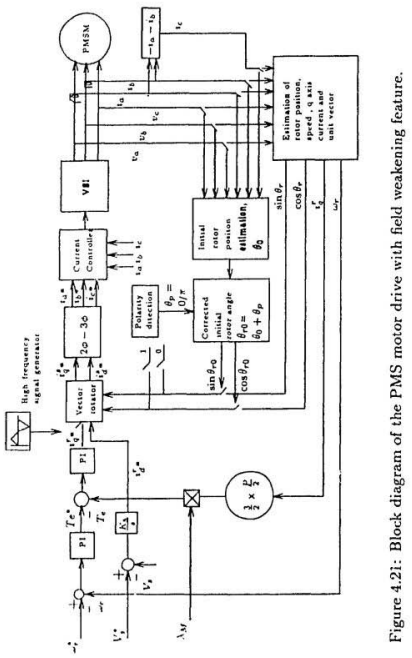


In Lriplace domain. it can le written that

$$
(1 ;-|i ;|(s)) \frac{k i}{s}=i(s)
$$

In difference equation form. it an be written as

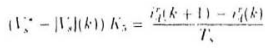

Or.

$$
r_{i}(k+1)=(1 ;-11 ;(k)) k_{s} T_{*}+i_{i}(k)
$$

Where $T$, is the simpling priml and $k+1 . k$ are the sulsecquent sompling instants.

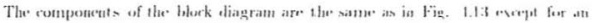

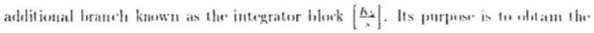
denagnetizing enront ahose the hase sperel. The computer simulation for this on

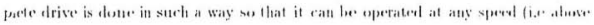

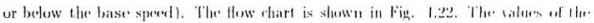
constants for PI rumbllors and the integratur are givell as follows:

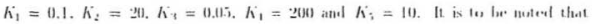
below the base sperel. the ituverter voltage varies linearly with spred aml rumstant

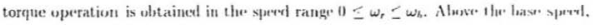

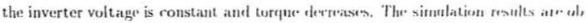
tained for twice the rated speed althongh the drive is capalble of oputating ot any

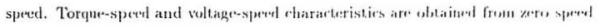

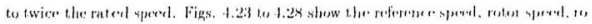

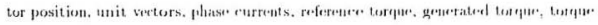

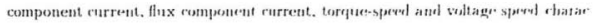
teristics, respectively. This driw system is rapable of opurating at any sparal giving. 

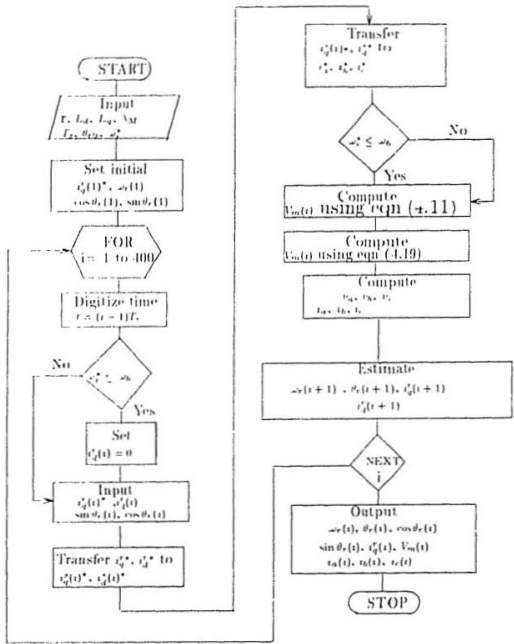

Finure Lez: Flow that for the computer simulation of PMS motor drive-operated at atiy spereil. 


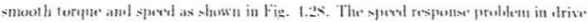
with only speed loup has been minimized in this complete drive lo interefuring an

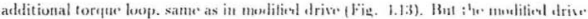

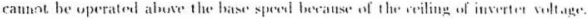

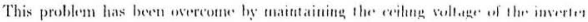

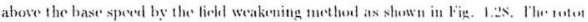
position aud the unit sertors obtained for this position sonsorless drise ate telaticels

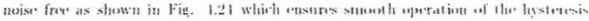
current cont rollix ant whage sumer incerter. 


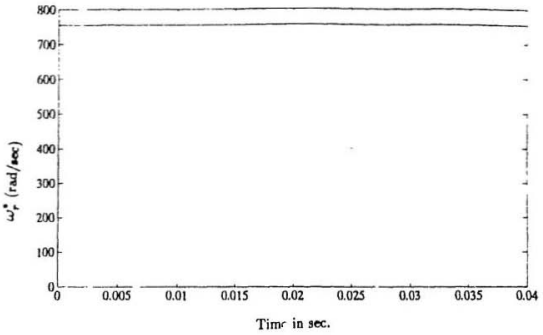

(a)

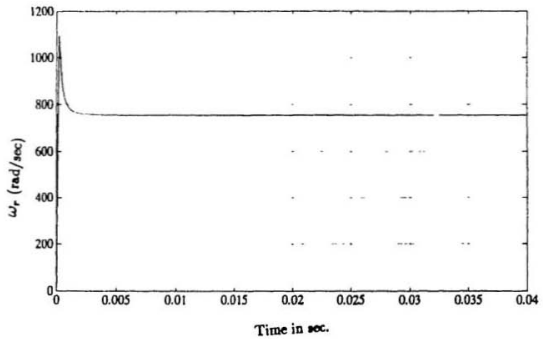

(b)

Fignre 4.23: Simulation of general PMS drive operated at various speeds. (a) Reference speed. (b) Actual speed. 


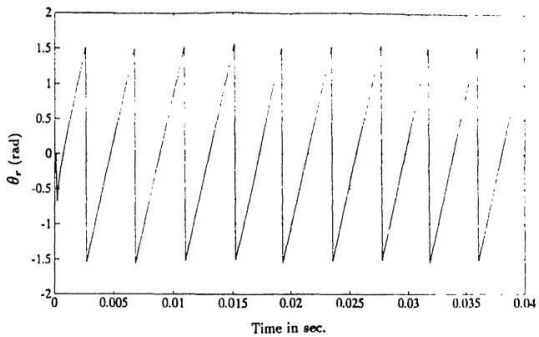

(a)

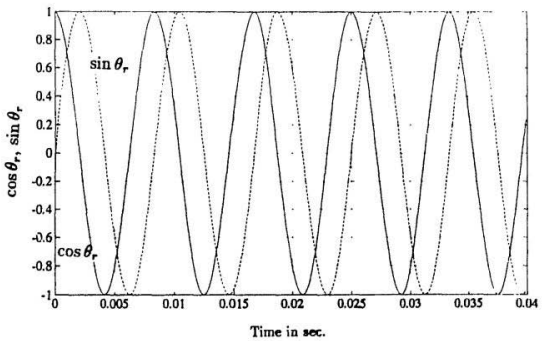

(b)

Figure 4.24: Simulation of general PMS drive operated at virious speceds. (a) Rotor position. (b) I nit vectors. 


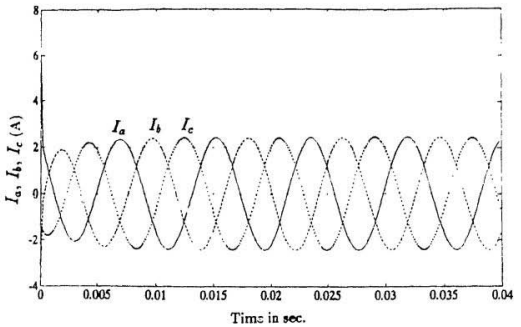

(a)

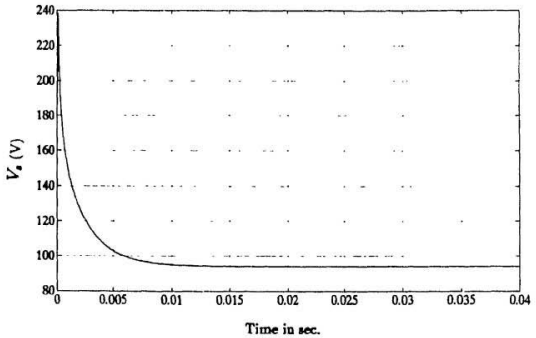

(b)

Figure 4.25: Silumlation of gencral PaIS drive operated at various speeds. (a) Phase currents. (b) Prak woltage of the inverter. 


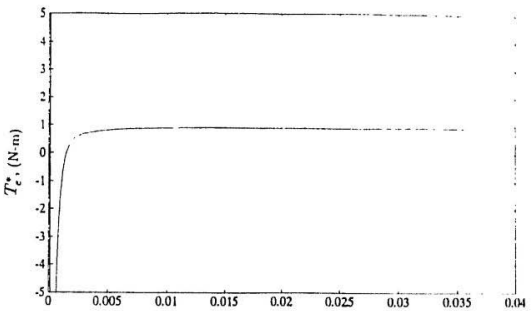

Time in sec.

(a)

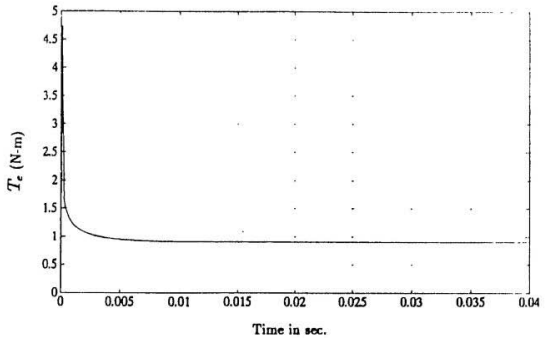

(b)

Figure 1.26: Simulation of general PMS drive operated at variuss speeds. (a) Mefrrence torque. (b) Generated torque. 


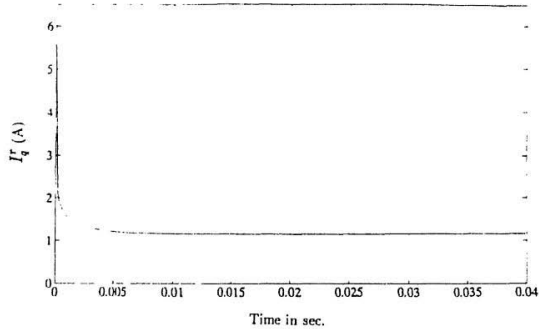

(a)

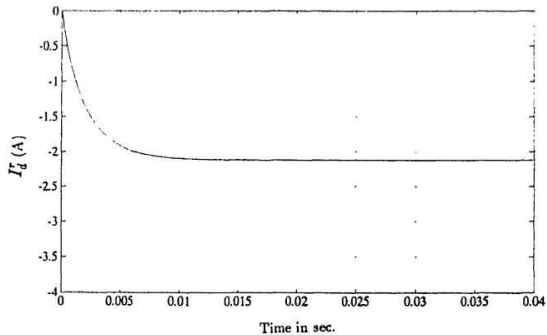

(b)

Figure 4.27: Simulation of general PMS drive operated at various speeds. (a) Torqque omponent current. (b) Demagnetizing current. 


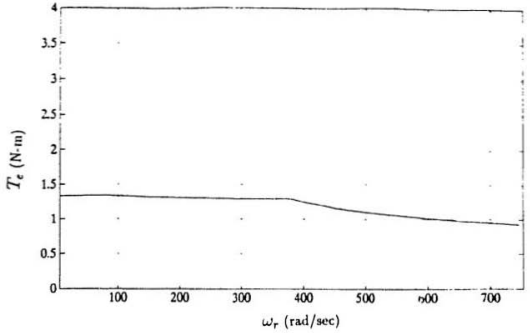

(a)

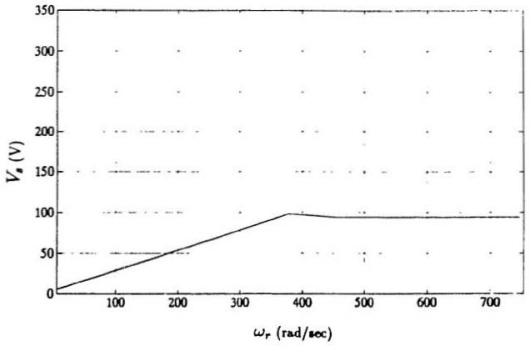

(b)

Figure 1.28: Simulation of general PMS drive operated at various speeds. (a) Tisrfue vs speed characteristics. (1) Voltage vs spmed characturisticts. 


\subsection{Discussions on Simulated Results}

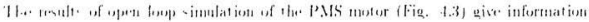

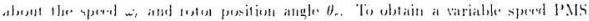

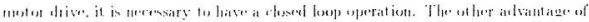

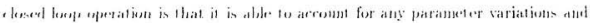

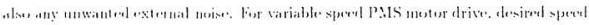

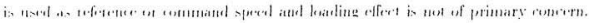

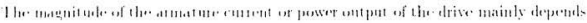

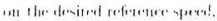

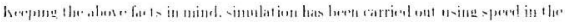

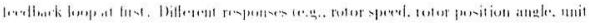

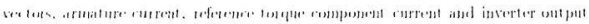

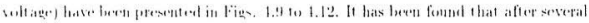

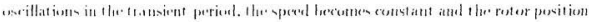

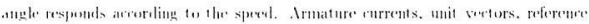

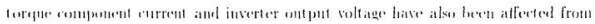

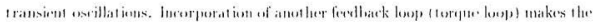

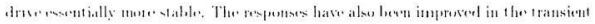

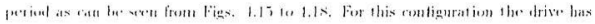

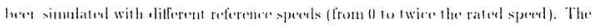

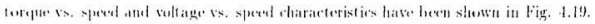

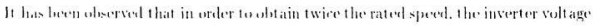

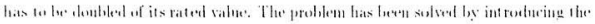

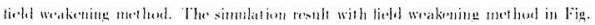




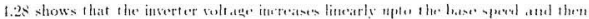
remains constant for the sulaspluent ipend.

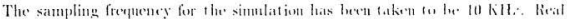

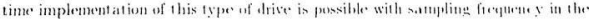
kilu-hertz ronge by using disp thatrel in-i]. 


\section{Chapter 5}

\section{Experimental Results}

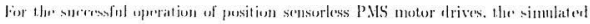
rotur pusition ander and rotor spend neerl to be verified experimentally before the implementation of the cout rol sithene. For this purposes a laboratory prototype

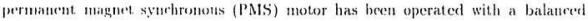

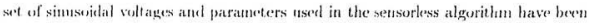
measured. Isime the measured parameters, the simulated results of the P.NS motor drive using sensorfess algurithe for the open loop condition have been verified. The As sign tata of the experimental PAls urotor is given in Appendix A.

\subsection{Determination of the magnet constant, $\lambda_{M}$}

In the sonsorless rotor position and rotor speed estimations (equations (3.17.1) and (3.17(ii). The magnet contsint of the P'MS motor, is one of the parameters which mests to la tarefully determined. The rotor of the experimental PMS motor used is the Neolymium Boron lron (NilBFe) permanent magnet. The B-If curve of the NellBFe magnets in the second quadrant is a straight line. Thus the magnet constant 


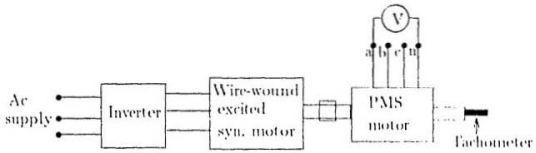

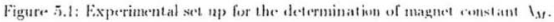

can be found from the folluwing inear relationship:

$$
I_{1 H}=\frac{1 \% \text { phetst }}{\omega_{r}(r \mathrm{r} t / \mathrm{s} r)}
$$

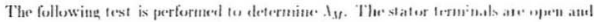

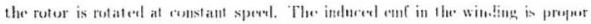
tional to the magnetic flux. I'sing the relationship of expation (5.1), Iy an thes

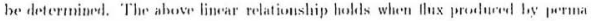
nent magnet rotor is considered as the straight line function of magne cousliant $\lambda_{a}$

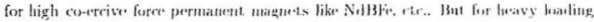

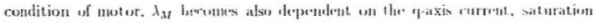
and other factors as well. Ilowever, propersed drive systems arr stable with a suall variation of $\lambda_{M}$. Hence the linear relationship for $\lambda_{A t}$ expressed in eepution $(5.1)$ ran be used for this present work.

The experimental set up for the idetormination of $\lambda_{M}$ is shown in Fig, 5.1 . The tosit

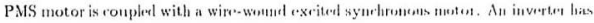

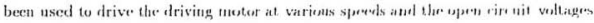

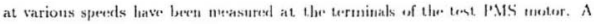
tachoncter is nsed to measure the rotur speed. The "xperimental results are given in 


\begin{tabular}{|c|c|c|c|c|c|c|}
\hline Sprectl. rриn & 231) & 769 & 1209 & 1800 & $2: 373$ & 3012 \\
\hline Voltage/to volt. & 9.2 & 30.3 & 47.8 & 71.1 & 93.9 & 119.3 \\
\hline$\lambda_{M r}$, vollt-s/rad & 0.27 & $0.266 i$ & $0.26 \tau$ & 0.267 & 0.267 & 0.267 \\
\hline
\end{tabular}

Tiable .5.1: Open cirruit voltage ancl magnet constant at, various specels of P.MS motor.

Tahle is.1. The average value of $\lambda_{y}$ hats been found as

$$
\lambda_{m}=0.26173
$$

The wave shipe or the incliecel voltage for the PMIS motor has bern shown in Apperulix 13.

The value of $\lambda_{14}$ fonud in the experiment is approximately constant at every speed. 'I'hu' same experinent has been repeaterl after muning the motor for several hours to herk whether there is any variation of $\lambda_{M}$ with temperature. No significant variation of $\lambda_{M}$ with ternperature was oliserwed..

\subsection{Verification of rotor position angle and speed using sensorless algorithm}

For the vertor control of the PNS motor, the speed $\left(\omega_{r}\right)$ and the rotor position angle $\left(\theta_{r}\right)$ needs to he seused. The present research deals with mechanical sensorless on line calculation of $\omega_{r}$ and $\theta_{r}$. For this purpose, expressions of $\omega_{r}$ and $\theta_{r}$ have been derived in chapter-there. The paraincters of the expressions for equations (3.17.4) and (3.176) are fiumd experimentally and using these parameters, the rotor position and rotor speed hate been sinulated for open loop condition. In addition, the input power, 


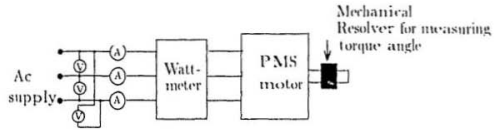

Figure 5.2: Experimental setup for the veritication of sensorless algurillam of IMS motor.

phase angle. torque angle have been foumd theoretionlly with these e'xpriment al pat rameters. Ifsing the two-wat t neter method, and monitoring the wolt atge and roment

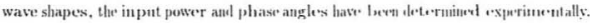

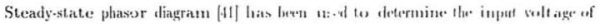

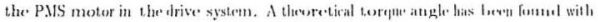
this vector diagram. A nechanical resolver is used in the determination of the forpune. angle of the PMS moter in the experiment. Thespeed $\omega$, obtainel in the axperiment is used in the following expression to find the rolor position.

$$
\theta_{t}=\int_{0}^{t} \omega_{r}(l)+\theta_{r}(0)
$$

The haboratory setup for the vrifiention of theretiral results of the somserless alge, rithm is shown in Fig. 5.2.

Simusoidal voltage is appliesl to the terminals of the P.MS motor. Three ammetres are connected in series in the three phases of the P.MS moter to determine the phase.

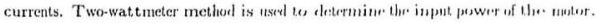

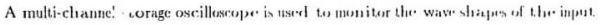
voltage and current in order to determitu the phase atgle. A disk is mounterl an the shaft of the motor which gives the direct axis pesition of the rotur. A pexitiun 


\begin{tabular}{|c|c|c|c|c|}
\hline P'NS notor & Infout power & ['/. suligle, $\gamma$ & Torry. angle. $\delta$ & Speerl. rpom \\
\hline Sinnulistinu & $6 i 2$ & $8: 3.6^{20}$ & $26^{\prime \prime}$ & 1810 \\
\hline Fixperiment & 66 & $80.4^{\prime \prime}$ & $23^{\circ}$ & 1800 \\
\hline
\end{tabular}

Table 5.2: Simulation and experinental results of open loup PMS notor.

\begin{tabular}{|c|c|c|c|c|c|c|c|c|c|}
\hline 1. nowe & 1) & i) & 10 & 15i & 20 & (25) & 30 & 35 & 40 \\
\hline Sim. 11 , in the & (1). & -75.5 & 32.4 & -39.5 & 68.4 & -3.5 & .75 .5 & 32.1 & -41.7 \\
\hline lixju, $\theta_{p}$, ta dist & 0.11 & -720 & 36.0 & -36.11 & 72 & 0 & .72 & 365 & $-3 i$ \\
\hline
\end{tabular}

Table 5.3: Simulation and experimental rotor position, $\theta_{r}$ of open loop PMIS motor.

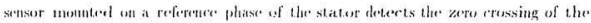
indered voltage. "Thus the phase displarement. between the applied voltage and in-

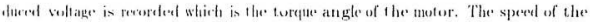

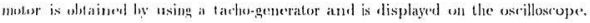
The simulation ant test results are tabulated in Thble 5.2. Simulation and experi. mential resultis for the rotor position angle are tabulated in Table 5.3. Fig. 5.3 shows the simulaterl and experiunetal rotur position. The plots of the experimental phase atmgle ans torque angle whained from the oscilloscope are given in Appendix $A$. 


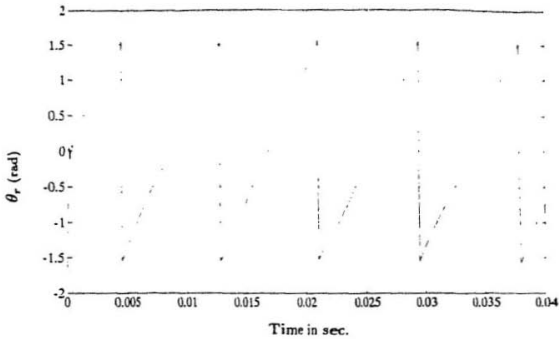

(a)

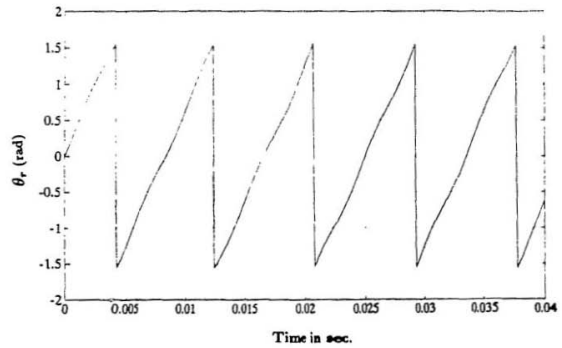

(b)

Figurt 5.4: Simulated and experimental results of open loop PMS motor: (a) Simulated rotor position angle (b) Experimental rotor position angle: 


\subsection{Discussions on the experimental results}

The coferefte of using starly-state phasor rliagrans to determine the input voltage of the drive system is appropriate as the toreque angle found with this phasor diagram is ahust. the same as that found experimentally. Thus. in the drive system, the

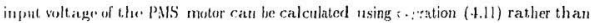
using adfitional sensors. This will not only simplify the systen but will make it less lulky. The theoretionl value of 0 , coneurs with the experimential value of $0_{r}$. thus

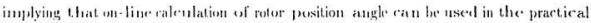

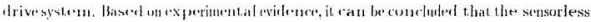

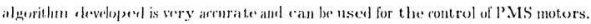
In pration, a last digital signal processor is used to implement this algorithm. The ixperimentation with TMSEVM:30 digital signal processor for the control of PMS mutor is under provess at the Power Bilectronics laboratory of Memorial Iniversity. This part is hyoud the stated scope of the prosent investigation. 


\section{Chapter 6}

\section{Conclusions}

This thesis explores the role of the PMS motor in Irive systems. Vertor control strategy has been considered for the uperation of the motor. This methenl menuirss information regarding the speed and position of the roter. Piliminatimg the require ment of mechanical sensors, this work develops an algorithen for on lime ralentition

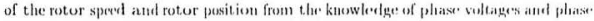
currents. Previous works used voltage semsers to mo asure the phase soltaige. In this

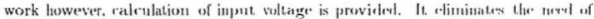
voltage sensors.

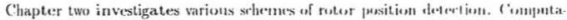
tion based rotor pusition detertion has burn rlasen for this work. In fhaperer three, general machine theory is analyzed at first and then P'ark's marhine mulel has iuv"n documented. Using axes transformation theserm, retor specerl and rotor pusition formulae have been derived in terms of machine parametors, phase. veltages and phias. currents. In chapter four, computer simulations have benell performanl for various con

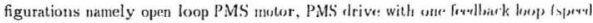
loop) and two feedhack loops (speed and torgue loopss). Baserd on the results of the 
simulations, it ran be contholed that the two-loup rive exhibits a bet ter transient

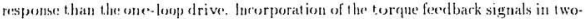
lienp drive systems would be able to rompensate for any instability which is likely to arise du. to the abrupt change: of lowd - a problem which is inherent in single loop drive: for varialise speed ar: motor drives, problems always arise when the unotor ruts above the base specd, beause the inverter voltage needs to be increased by an expat anomut ter baliure the batk emot which is proportional to the speed. Field weakening

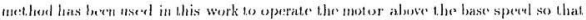
the inverter voltage remains coustant beyond the rated spered. (imputer simulation

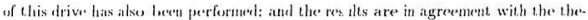

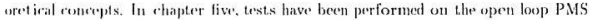
motor and the that a ohained from the usts have been used ter verify the semsorless

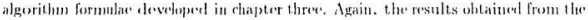

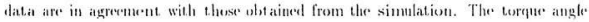
whatined from the calenlation of the input voltage of the motor is in agresenent with that, ubtaimen exprementally, thus confirming that the operation of a sensorless PMS Irive is pussible without the physiral mensurement of the input voltage.

\subsection{Recommendations for future research}

This lhesis primarily lisases on the computer simulation of speed and position sensurhas PMS drive systems. The following recommendations have been made for the real tinte implementat ion of the propusad drive.

Siture the work de dis with the computation bascd rotor position detection terhnique fior the vertor entrol of P.IS notors, high speed digital signad processor felspl 
is a tool for the real time implenentation of this project. Fexis lustmument T.II SEVM[30 dap is capable of performing floating point calculations with ext rathelitiary

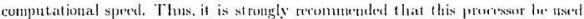
for future researth. Suitalaly programuning the processor. which will aliminate the need for arious controllers in the drise system is also reenmmended. This will in effect greatly enhance the plliciency of the sys: 


\section{References}

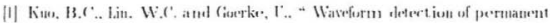

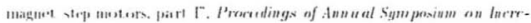

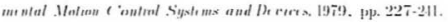

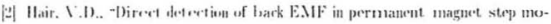

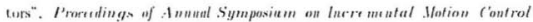

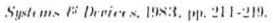

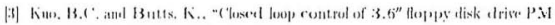

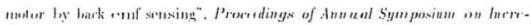

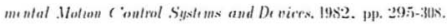

HI Sinfert. W., "Self syu-hronization of permanent magnet energized stepper notor with deteretion of position hy evaluation of the BEMIF. I'roredings

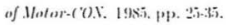

[5] Antognini, L.. - Dynanic tornte optimisation of as step motor ly bark emf stusing". Protudings of thanal Sympexium on Incremental Holion Crintrol

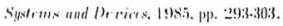


[6] lizuka. K.. I'zuhashi. H.. K.anu. M.. Finh, I. uni Mohrs, K.. Mn ro rum

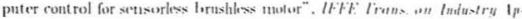

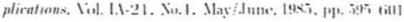

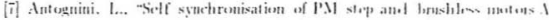

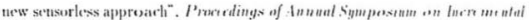

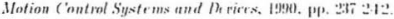

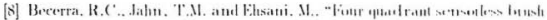

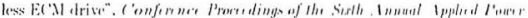

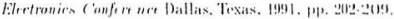

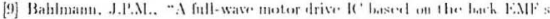

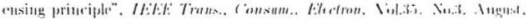
1989. (3p. $115-120$.

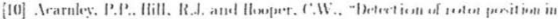

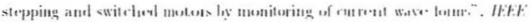

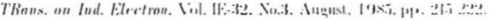

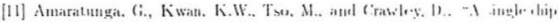

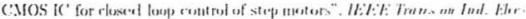

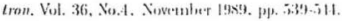

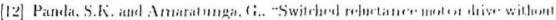

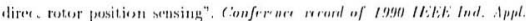

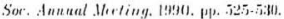




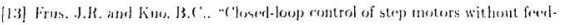

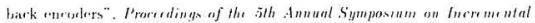

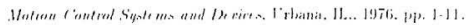

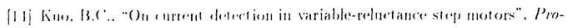

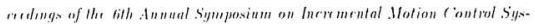

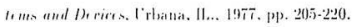

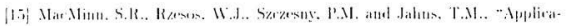

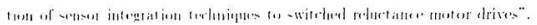

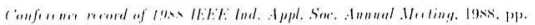
inlinit.

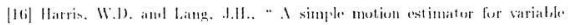

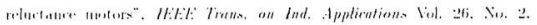
Matrly! Ipril 1!19H. Wr. $23, \geq 13$.

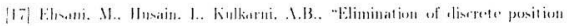
s\%.

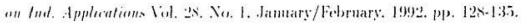

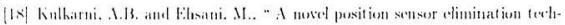

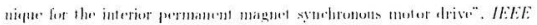

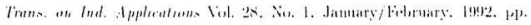
| 1. 1. 1).

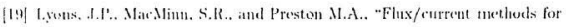
Slid rotor pusition ostimation". conference record of l.99l IEEE Ind. Appl.

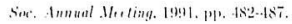




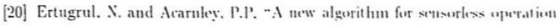

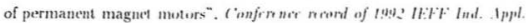
Sor. Annual Merting. 1!392. Pp. 111-121.

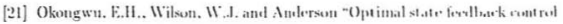

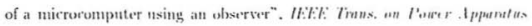

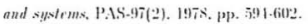

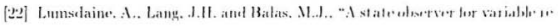

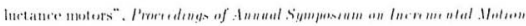

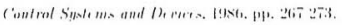

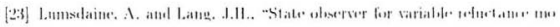

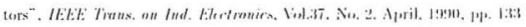
$1 \cdot 12$.

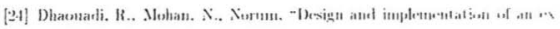

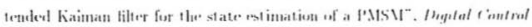

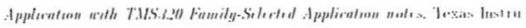

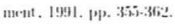

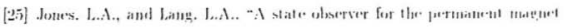

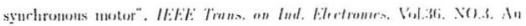
gust. 1!35!). pp. 37+1-3<2.

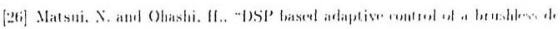

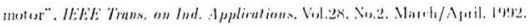
131. 4 4. 454 . 
[27] Matsui. X. and Shigyo. M.. "Brushless de mutor witlont position and speed smisrse", IEEE Trrons, on Ind. Applications. Vel.2s. No.1. Jan.

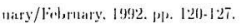

[2S] Takahasthi. 1. ant Jwata. W..."Jligh resolution position rontrol uncler 1 sec. of an 1.M with full digitizent nethor", Conferener Rrowl of the 1989 IEEE lust. Appl. Sor. Anumal Werting, 1989, pp. 632-6:38.

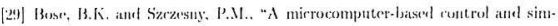

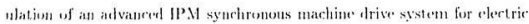

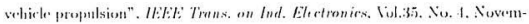
her. I!ks. pu. stom-int.

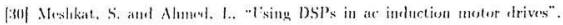

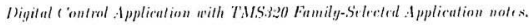
Tixas Instrumunt, 199)1, p1, 3013-3066.

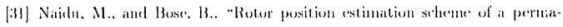

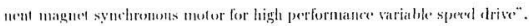

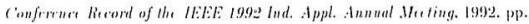
IS-ii3.

[i2] Steingrimsson. 11. and Astrom. J.K. "DSP implementation of a disk drive

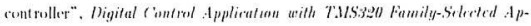
plication notex. Texas lnst rument. 1991. p], 2:39-253.

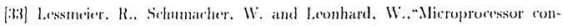
trolled ac servo drise's with synthronous or induct ion motors: which is prefer- 


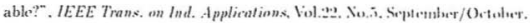
1986. pp. \$12-819.

[3-1] Kume. T. ant lwakan: T. "High performance wertur nout rullexl at metor drives: Applications and new lechoolegios". IEFE Irans. an Ind. Ipplaca.

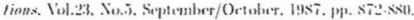

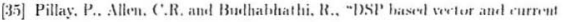

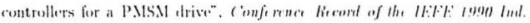

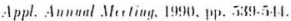

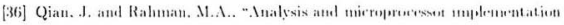

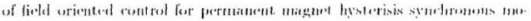

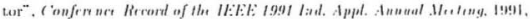
11). $19 \times-203$.

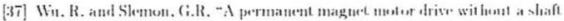

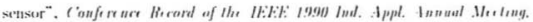

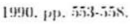

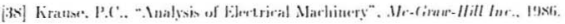

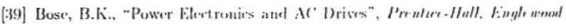
(Viffs, N./. 1986.

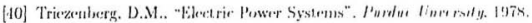

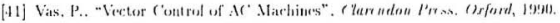




\section{Appendix A}

\section{PMS motor design data}

Ratiol power $=1 \mathrm{hp}$.

Number of poles $=1$

Hatse s|res| wh $=37 T \mathrm{rat} /$ sar.

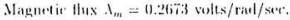

Stator resistaner $r=2,7 \Omega$.

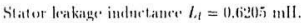

q-ixis magnetizing induetance. $l_{n q}=7.56 \mathrm{mll}$.

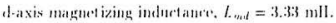

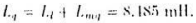

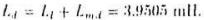




\section{Appendix B}

\section{Experimental waveforms}



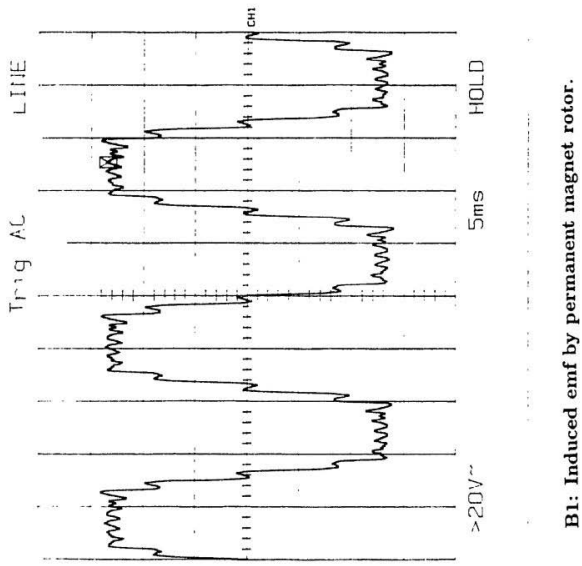

L

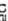




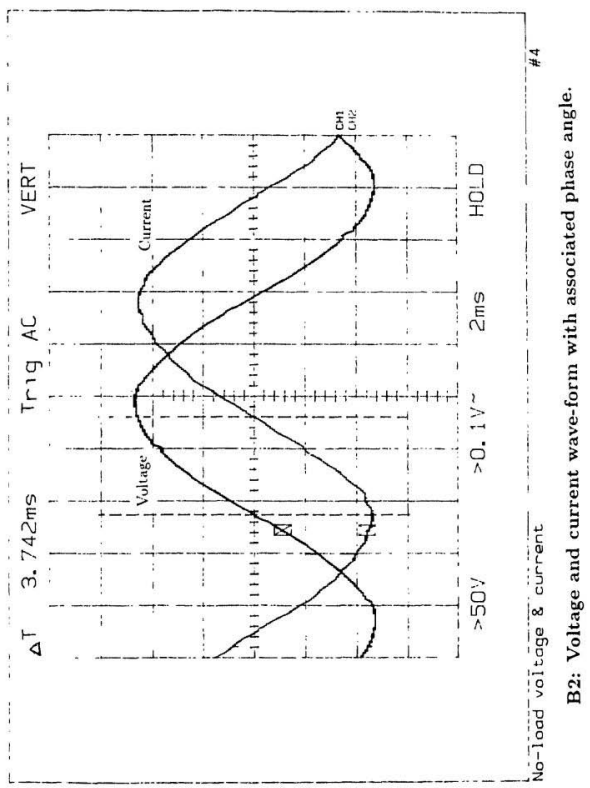




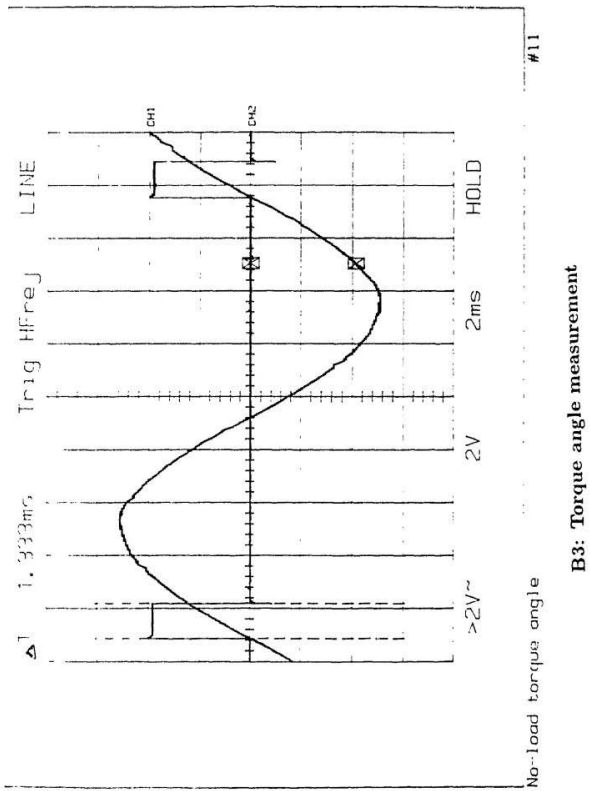





